\title{
Chemical Constituents of Psychotria nemorosa Gardner and Antinociceptive Activity
}

\author{
Nivea O. Calixto, ${ }^{a}$ Millena S. Cordeiro, ${ }^{b}$ Thais B. S. Giorno, ${ }^{b}$ Gibson G. Oliveira, ${ }^{c}$ \\ Norberto P. Lopes, ${ }^{c}$ Patricia D. Fernandes, ${ }^{b}$ Angelo C. Pinto ${ }^{\dagger, a}$ and Claudia M. Rezende ${ }^{*, a}$ \\ ${ }^{a}$ Instituto de Química and ${ }^{b}$ Instituto de Ciências Biomédicas, Universidade Federal do Rio de Janeiro, \\ 21949-900 Rio de Janeiro-RJ, Brazil \\ ${ }^{c} N P P S$ - Faculdade de Ciências Farmacêuticas de Ribeirão Preto, Universidade de São Paulo, \\ 14040-903 Ribeirão Preto-SP, Brazil
}

\begin{abstract}
Through dereplication strategies using gas chromatography-mass spectrometry (GC-MS) and ultra fast liquid chromatography-tandem mass spectrometry (UFLC-MS/MS), the ethanol extract from Psycotria nemorosa leaves (Rubiaceae) showed to be composed of: cinnamic acid, dihydroactinidiolide, 4-hydroxy- $\beta$-ionone, phytol, isophytol, 4,8,12,16-tetramethylheptadecan4-olide, lupeol, a mixture of $\alpha / \beta$-amyrin, the keto and acetylated derivatives, besides stigmast4-en-3-one, campesterol, stigmasterol and $\gamma$-sitosterol by GC-MS. Likewise, by UFLC-MS/MS, the main compounds identified were: butin, resveratrol, rutin, kaempferol 7- $O$ - $\beta$-D-glucopyranoside, deacetylasperuloside, epiloganin, hordenine, strictosidine, $N$-methyl-1,2,3,4-tetrahydro- $\beta$-carboline and $N$-formyl-tryptamine. The antinociceptive activity of the crude extract ant its fractions was reported.
\end{abstract}

Keywords: Psychotria nemorosa, hyphenated chromatography-mass spectrometry, antinociceptive activity

\section{Introduction}

Herbal drugs have been used since ancient times as medicines, for the treatment of a range of diseases. Many modern drugs have been evolved from ethnopharmacological approaches. ${ }^{1,2}$ Discovery of novel bioactive compounds from plants is a challenging, laborious, expensive process and requires long time to isolate and characterize an active compound. If the isolated bioactive is a known compound, then the time and resources spent on it will be quite a wasted effort. ${ }^{3}$ To overcome these issues, new techniques for direct identification of bioactive natural products from extracts were developed. Recent high throughput assays technologies to study plant extracts for biological activity has intensified the need for appropriate dereplication strategies. ${ }^{4}$ Dereplication is the process that allows a rapid identification of secondary metabolites in crude extracts by distinguishing previously identified compounds from novel ones. The dereplication process involves separation of single metabolites by chromatographic methods,

\footnotetext{
*e-mail: claudia.rezendeufrj@gmail.com
}

†n memoriam identification by spectroscopic methods, bioassay for evaluation of the biological activity, and search in databases to verify the novelty of these compounds. ${ }^{5}$

Hyphenated chromatographic techniques possess characteristics that include efficient separation and rapid identification, among several other advantages in comparison with other analytical methods. These techniques bring significant improvements in the identification of novel natural compounds in complex matrices. ${ }^{6,7}$

Psychotria comprises an important genus of Rubiaceae family and contains approximately 1700 species of flowering plants with tropical and subtropical distribution. ${ }^{8}$ The polyphyly of the genus has been demonstrated through recent worldwide molecular phylogenetic studies. Razafimandimbison et al. ${ }^{9}$ established that Psychotria includes all its allied genera, rendering the tribe Psychotrieae monogeneric. It is commonly used in folk herbal medicine for regulating menstrual disturbance, fever, against microbial infections, anti-inflammatory, analgesic, anticonvulsant, anti-rheumatic and even as cardiovascular, mental and eating disorders. ${ }^{10-13}$ Psychotria genus is a source of alkaloids, but other compounds like terpenes, flavonoids, tannins, coumarins and cyclotides (circular peptides) has also been isolated..$^{14-17}$ 
Psychotria nemorosa Gardner (Rubiaceae), popularly known as "casca d'anta", is a native terrestrial substrate shrub measuring 1-2 $\mathrm{m}$ in height with endemic growth in Brazil, found in Rain Forests in the states of Bahia, Paraíba (Northeast), Goiás (West-Central), Espírito Santo, Minas Gerais, Rio de Janeiro, São Paulo (Southeast), Paraná, Santa Catarina and Rio Grande do Sul (South).$^{18}$ It is characterized by persistent bilobed stipules containing 8 to 10 arched secondary ribs on each side and visibles cross linked tertiary ribs. Flowering and fruiting occurs in January and March, respectively. ${ }^{19}$

Literature review showed that the extracts of many Psychotria species have anti-inflammatory and analgesic activity, and preliminary tests pointed to alkaloids as the major responsible for the effect, besides other compounds. ${ }^{20,21}$ Pain is a protective mechanism, triggered by potentially injurious stimuli, that influences the quality of life and is directly related to a high amount of medical licenses all over the world. ${ }^{22,23}$ Usually, the therapeutic profile is based on analgesic and anti-inflammatory drugs that present several side effects as ulcers, vomiting, tolerance or dependence. ${ }^{24}$ Due to these problems, there is continuous interest in the search of new substances that could act with lesser side effects.

As far as we know, no record on phytochemical studies nor biological approach of $P$. nemorosa is described in scientific literature. So, in this work, our objective was to investigate the chemical composition of the P. nemorosa leaves on a metabolomic approach and its antinociceptive property in mice.

\section{Experimental}

\section{General experimental procedures}

All solvents were high-grade purity purchased from Tedia (Brazil). Infrared (IR) spectra were recorded on a Nicolet Magna IR 760 spectrometer using $\mathrm{KBr}$ pellets. Column chromatography was performed over silica gel (25 g, 200-300 mesh, Silicycle, Canada) and thin layer chromatography (TLC) on precoated silica gel $\mathrm{GF}_{254}$ aluminum plates (Merck, Germany). Spots were visualized by spraying with acidic cerium (IV) sulfate reagent followed by heating at $110{ }^{\circ} \mathrm{C}$ and usual specific reagents for different classes of natural product.

\section{Plant material}

Leaves of P. nemorosa Gardner were collected in November (2012) at Serra dos Órgãos (Rio de Janeiro State, Southeast of Brazil, -22.464042, -43.011746). The access authorization number is 27035-4 emitted by Ministério do Meio Ambiente. A voucher specimen (Trovó 389 RB) was deposited at the herbarium of the Jardim Botânico do Rio de Janeiro and identified by Marcelo Trovó Lopes de Oliveira.

\section{Extraction and isolation}

Dried leaves $(60 \mathrm{~g})$ were exhaustively extracted with a $90 \%$ aqueous ethanol (EtOH) solution at room temperature for 7 days. The resulting extracts were combined and concentrated under low pressure at $40^{\circ} \mathrm{C}$ in a rotaevaporator to yield a dark green liquid (crude ethanolic extract (EE), $7 \mathrm{~g})$. EE (1.0 g) was dissolved in $\mathrm{MeOH}$ and subjected to silica gel column chromatography $(\mathrm{CC})(21 \times 2.5 \mathrm{~cm})$ eluted with hexane, a gradient of hexane/ethyl acetate (EtOAc) $(5,10,20,50$ and 100\%) and methanol $(\mathrm{MeOH})$ to afford thirty-five fractions, which were combined in twelve resulting fractions according to TLC analysis (Table S1, Supplementary Information).

Gas chromatography-mass spectrometry (GC-MS)

GC-MS analyzes were performed on a gas chromatograph coupled to a mass spectrometry (GCMS-QP 2010 Ultra, Shimadzu, Kyoto, Japan) equipment with a quadrupole mass analyzer, electron impact ion source (at $70 \mathrm{eV}$ ), auto sampler AOC-20s and auto injector AOC-20i. Analyzes were carried out using a DB-1 capillary column of $30 \mathrm{~m} \times 0.25 \mathrm{~mm} \times 0.25 \mu \mathrm{m}$, helium as carrier gas at $1.0 \mathrm{~mL} \mathrm{~min}^{-1}$. The $\mathrm{GC}$ temperature was programmed as: $60^{\circ} \mathrm{C}$ (2 min), 60-120 ${ }^{\circ} \mathrm{C}\left(6^{\circ} \mathrm{C} \min ^{-1}\right), 120-290{ }^{\circ} \mathrm{C}\left(15^{\circ} \mathrm{C} \mathrm{min}^{-1}\right)$ then $290^{\circ} \mathrm{C}$ for $17 \mathrm{~min}$, according to Patitucci et al. ${ }^{25}$ Injector, ion source and interface temperatures were 280, 230 and $290^{\circ} \mathrm{C}$, respectively. Data acquisition was performed by Lab Solutions Software and data analysis by NIST MS search database. The sample injection volume was $1.0 \mu \mathrm{L}$, all diluted with EtOAc. The triterpenes were identified by comparison of the retention time with authentic standards. $N$-Octadecane was used as internal standard in gas chromatography coupled to a flame ionization detector (GC-FID) with the same conditions described above.

\section{Oxidation of triterpenes}

\section{$\beta / \alpha$-Amyrin acetate $(20 a, 20 b)$}

$\beta / \alpha$-Amyrin (31a, 31b) (0.05 g), acetic anhydride $(1.5 \mathrm{~mL})$ and DMAP $(0.001 \mathrm{~g})$ were mixed, stirred and heated under reflux. The reaction was monitored by TLC $(2 \mathrm{~h})$, then diluted with $\mathrm{H}_{2} \mathrm{O}(4 \mathrm{~mL})$ and extracted with dichloromethane $\left(\mathrm{CH}_{2} \mathrm{Cl}_{2}\right)(3 \times 10 \mathrm{~mL})$. The combined organic phases were dried over $\mathrm{Na}_{2} \mathrm{SO}_{4} \cdot{ }^{26} \mathrm{After}$ evaporation, 
a white solid of $\beta / \alpha$-amyrin acetate (20a, 20b) was obtained (49.0 mg, 98\%). IR (KBr) $v_{\max } / \mathrm{cm}^{-1}: 2949$ (=C-H), 1734 $(\mathrm{C}=\mathrm{O}), 1379,1367(\mathrm{C}-\mathrm{H}), 1246(\mathrm{C}-\mathrm{O}) ; \beta$-amyrin acetate (20a) MS m/z (\%): $468\left(\mathrm{M}^{+}, 3\right), 218$ (100), 203 (52), 189 (24); $\alpha$-amyrin acetate (20b) MS m/z (\%): $468\left(\mathrm{M}^{+}, 4\right)$, 218 (100), 203 (23), 189 (27). Lupeol acetate (48 mg, 96\%). IR $(\mathrm{KBr}) v_{\max } / \mathrm{cm}^{-1}: 2943(=\mathrm{C}-\mathrm{H}), 1732(\mathrm{C}=\mathrm{O}), 1639$ (C=C), 1454, $1367(\mathrm{C}-\mathrm{H}), 1249$ (C-O); MS m/z (\%): 468 $\left(\mathrm{M}^{+}, 20\right), 408(20), 218(36), 204(44), 189(100)$.

\section{$\beta / \alpha$-Amyrone (18a, 18b)}

Jones' reagent was added dropwise to the $\beta / \alpha$-amyrin (31a, 31b) $(0.05 \mathrm{~g})$ in acetone $(5.0 \mathrm{~mL})$ at room temperature until the red-orange color of the oxidant persisted. Drops of isopropanol were added until the appearance of a bluegreen color, followed by water addition ( $3.0 \mathrm{~mL}$ ), a $\mathrm{Na}_{2} \mathrm{CO}_{3}$ saturated solution and extraction with $\mathrm{CH}_{2} \mathrm{Cl}_{2}(3 \times 10 \mathrm{~mL}){ }^{27}$ The combined organic layers were dried over $\mathrm{Na}_{2} \mathrm{SO}_{4}$ and evaporated to give off-white crystals of amyrones $(48.5 \mathrm{mg}$, 97\%). IR (KBr) $v_{\max } / \mathrm{cm}^{-1}: 2948(=\mathrm{C}-\mathrm{H}), 2853(\mathrm{C}-\mathrm{H}), 1706$ $(\mathrm{C}=\mathrm{O}), 1456,1380(-\mathrm{C}-\mathrm{H}) ; \beta$-amyrone (18a) MS m/z (\%): $424\left(\mathrm{M}^{+}, 11\right), 218$ (100), 203 (57), 189 (19); $\alpha$-amyrone (18b) MS m/z (\%): $424\left(\mathrm{M}^{+}, 11\right), 218$ (100), 203 (23), 189 (19).

\section{3,11-Dioxo- $\beta / \alpha$-amyrene (21a, 21b)}

tert-Butyl chromate $(3.0 \mathrm{~mL})$ was added to a solution of $\beta / \alpha$-amyrone (18a, 18b) $(20 \mathrm{mg})$ in acetone $(2.0 \mathrm{~mL})$, acetic anhydride $(3.0 \mathrm{~mL})$ and acetic acid $(6.0 \mathrm{~mL})$, refluxed for $6 \mathrm{~h}$ and at the end diluted with $\mathrm{H}_{2} \mathrm{O}(2.0 \mathrm{~mL})$ and extracted with $\mathrm{CH}_{2} \mathrm{Cl}_{2}(3 \times 10 \mathrm{~mL})$. The organic phase was washed with aqueous oxalic acid solution $5 \%(2 \times 10 \mathrm{~mL}), \mathrm{Na}_{2} \mathrm{CO}_{3}$ saturated solution $(10.0 \mathrm{~mL})$ and $\mathrm{H}_{2} \mathrm{O}(10.0 \mathrm{~mL})$, then dried over $\mathrm{Na}_{2} \mathrm{SO}_{4}$ and evaporated. ${ }^{28}$ The product was a yellowish oil (17.6 mg, 88\%). IR (KBr) $v_{\max } / \mathrm{cm}^{-1}: 2976$ (=C-H), 2872 $(-\mathrm{C}-\mathrm{H}), 1709,1663(\mathrm{C}=\mathrm{O}), 1457(\mathrm{C}=\mathrm{C})$; 3,11-dioxo- $\beta$ amyrene (21a) MS m/z (\%): $438\left(\mathrm{M}^{+}, 31\right), 273$ (75), 232 (93), 217 (28), 135 (100); 3,11-dioxo- $\alpha$-amyrene (21b) MS m/z (\%): 438 (M+1 19), 273 (100), 232 (54), 217 (9), 135 (76).

Ultra fast liquid chromatography-mass spectrometry (UFLC-MS)

UFLC-MS analyzes were performed on a Shimadzu UFLC (UFLC Shimadzu System Proeminene, Kyoto, Japan), consisting of a binary pump solvent management system, an online degasser, an auto-sampler, a column oven and a photo diode array detector (DAD). Separation was performed on a Phenomenex Luna C18 (2) 100 A $(250 \times 4.6$ mm i.d., $5 \mu \mathrm{m})$ column equipped with a Phenomenex Luna C18 guard column $(4.3 \times 5 \mathrm{~mm}$; Phenomenex, California, USA). The mobile phase consisted of water (A) and acetonitrile (B) both containing $0.1 \%$ formic acid (v/v), with a gradient elution: 0-50 min: 5-100\% B (linear gradient); 50-55 min: 100\% B (isocratic gradient); 55-60 min: 100-5\% B (column washing); 60-65 min: $5 \%$ B (isocratic, column equilibration). The flow

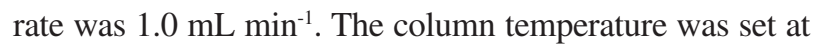
$35^{\circ} \mathrm{C}$ and the injection volume was $20 \mu \mathrm{L}$. The UV spectra were recorded from 200 to $800 \mathrm{~nm}$. The UFLC system was coupled to a micrOTOF-II mass spectrometer equipped with an electrospray interface (ESI) (Bruker Daltonics Inc., Billerica, MA, USA) operating in both positive and negative ion mode using a capillary voltage of $3.5 \mathrm{kV}$, end plate $500 \mathrm{~V}$ to obtain the accurate mass data. The parameters for ESI coupled to quadrupole-time-of-flight mass spectra (ESI-QTOF-MS) were: drying gas temperature, $320^{\circ} \mathrm{C}$; drying gas flow, $10 \mathrm{~L} \mathrm{~min}^{-1}$ and nebulizing gas pressure, $60 \mathrm{psi}$. Detection was carried out within a mass range of 50-1300 Da. Nitrogen was used as drying, nebulizing and collision gas.

Similar UFLC equipment and chromatographic conditions were used, as described above, coupled to a mass spectrometer ESI-IT (Bruker Daltonicx, Billerica, MA, USA), fitted with an electrospray ionization source operating in positive and negative mode and ion-trap analyzer. Tandem mass spectrometry $\left(\mathrm{MS}^{2}\right)$ analyzes were developed in this equipment. The mass spectrometer parameters used were: capillary voltage, $3.5 \mathrm{kV}$; dessolvation temperature, $330{ }^{\circ} \mathrm{C}$; gas flow, $10 \mathrm{~L} \mathrm{~min}^{-1}$ and pressure at $60 \mathrm{psi}$. Nitrogen was used as both drying and nebulizing gas. Amplitude fragmentation energy for MS/MS experiments was $0.70 \mathrm{~V}$. Data analysis was carried out with Bruker Daltonics software version 4.1.

\section{Animals}

All experiments were performed with male Swiss Webster mice (20-25 g) obtained from our own animal facilities. Animals were kept in a room with controlled temperature $22 \pm 2{ }^{\circ} \mathrm{C}$ for $12 \mathrm{~h} \mathrm{light/dark} \mathrm{cycle} \mathrm{with}$ free access to food and water. Twelve hours before each experiment, the animals received only water, in order to avoid food interference with substances absorption. Animal care and research protocols were in accordance with the principles and guidelines adopted by the Brazilian College of Animal Experimentation (COBEA), approved by the Biomedical Science Institute/UFRJ, Ethical Committee for Animal Research, and received the number DFBCICB015-04/16.

\section{Psychotria nemorosa fractions administration}

P. nemorosa (leaves) fractions were dissolved in dimethyl sulfoxide (DMSO) in order to prepare a stock solution at a 
concentration of $100 \mathrm{mg} \mathrm{mL}^{-1}$. In all experiments, the final concentration of DMSO did not exceed $0.5 \%$ at which it has no effect per se. The crude extract (EE), hexane, hexane/ EtOAc 5\%, hexane/EtOAc 10\%, EtOAc and MeOH fractions were administered by oral gavage at 10,30 or $100 \mathrm{mg} \mathrm{kg}^{-1}$ in a final volume $0.1 \mathrm{~mL}$. The control group was composed by vehicle (ultrapure water), which was the same used to solubilize the EE and fractions that were administered on the day of the experiment.

\section{Formalin-induced licking response}

This procedure was similar to the method described by Gomes et al. ${ }^{29}$ Mice received an injection of $20 \mu \mathrm{L}$ of formalin $(2.5 \% \mathrm{v} / \mathrm{v})$ into the dorsal surface of the left hind paw. The time that the animal spent licking the injected paw was immediately recorded. The nociceptive and inflammatory response consists of the following two phases: the first phase lasts until $5 \mathrm{~min}$ after the formalin injection (first phase, neurogenic pain response), and the second phase occurs 15-30 min after the formalin injection (second phase, inflammatory pain response). The animals were pre-treated with oral doses of EE, hexane, hexane/ EtOAc 5\% and hexane/EtOAc 10\% fractions, EtOAc and $\mathrm{MeOH} 60 \mathrm{~min}$ before the administration of formalin.

\section{Statistical analysis}

Each experimental group consisted of 6 mice. The results are presented as mean \pm standard deviation (S.D.). The area under the curve (AUC) was calculated using Prism Software 5.0 (GraphPad Software, La Jolla, CA, USA). Statistical significance between groups was determined using the application of analysis of variance (ANOVA) followed by Bonferroni's test. $p$-Values less than 0.05 were considered to be significant.

\section{Results and Discussion}

The crude ethanolic extract (EE) from leaves of $P$. nemorosa was fractionated in a silica gel open column chromatography affording twelve fractions, all analyzed by TLC. Each fraction was evaluated by GC-MS or liquid chromatography coupled to mass spectrometry (LC-MS) on a metabolomic perspective based on their polarities. Mass spectrometry (MS) allows a direct screening of the compounds, providing structural information without the need of laborious isolation since each family of metabolites may have a characteristic mass fragmentation pattern and retention times in GC-qMS and typical UV absorption and MS/MS profile in LC-DAD-MS/MS systems. ${ }^{30}$
In addition, fractions and EE were evaluated for antinociceptive properties on formalin-induced licking response in mice due the occurrence of two distinct phases of nociceptive behavior: one phase immediately after the injection, lasting for about $5 \mathrm{~min}$, and the other phase starting approximately $20 \mathrm{~min}$ after the injection. ${ }^{31}$

The fractions resulting from the CC silica gel can be seen in Table S1 (Supplementary Information). Only those with sufficient amount to access biological activity were investigated in the phytochemical approach. To identify the less polar compounds, GC-MS was used and their profiles are shown in Figures 1A-1D.

GC-MS chemical compounds present in fractions 1, 5, 8 and 9 can be seen in Tables S2 and S3 (Supplementary Information). The MS of the compounds showed more than $90 \%$ of similarity with NIST database. These results attested to the major occurrence of cinnamic acid, sterols (campesterol, stigmasterol, $\gamma$-sitosterol and stigmast-4-en-3-one) and pentacyclic triterpenes such $\alpha / \beta$-amyrone, $\alpha / \beta$-amyrin acetate, 3,11-dioxo$\alpha / \beta$-amyrene, lupeol and $\alpha / \beta$-amyrin, besides some fatty acids, diterpene alcohols and hydrocarbons. Co-injection with authentic materials additionally confirmed the identification. It is important to report that fractions 15-22 were not investigated by GC-MS due to their increased polarity and also due to the small amounts for biological assays. Figure 2 shows the chemical structures of the compounds identified in this work.

Although Psychotria genus is characterized mainly as a source of alkaloids, the occurrence of terpenoids is well known. In P. yunnamensis, norisoprenoids and the monoterpenoid (6S)-menthiafolic acid were isolated, in addition to the ancorane sesquiterpene psycacoraone A. ${ }^{32,33}$ Volatile compounds were also detected in P. leiocarpa. ${ }^{34}$

$\beta$-Sitosterol was found in P. mariniana and P. hainanensis, together with stigmasterol in $P$. vellosiana. ${ }^{17,35,36}$ These steroids, in the glycosylated form, were also reported. ${ }^{36-38}$

Lupeol was found in $P$. vellosiana and $P$. mariniana. ${ }^{17,35}$ Phytochemical studies of $P$. adenophylla allowed the caracterization of other triterpenes such as bauerenol, bauerenol acetate, friedelin, betulin, ursolic acid, traces of $\alpha$-amyrin and betulinic acid. ${ }^{39}$ Ursolic acid was isolated from $P$. serpens.$^{40}$ Besides $P$. adenophylla, $\alpha$-amyrin was also found in $P$. stachyoides.${ }^{37}$ It should be emphasized that the occurrence of $\alpha / \beta$-amyrone, $\alpha / \beta$-amyrin acetate and 3,11-dioxo- $\alpha / \beta$-amyrene is being reported for the first time in Psychotria genus. $\alpha / \beta$-Amyrone $(\mathrm{m} / \mathrm{z}, 424$, $\left.[\mathrm{M}]^{+*}\right)$ and $\alpha / \beta$-amyrin acetate $\left(\mathrm{m} / \mathrm{z} 468,[\mathrm{M}]^{+*}\right)$ showed ions at $\mathrm{m} / \mathrm{z}, 218$ due to a typical retro Diels-Alder reaction $\left([\mathrm{M}]^{+\bullet}-\mathrm{C}_{14} \mathrm{H}_{22} \mathrm{O}\right.$ and $[\mathrm{M}]^{+\bullet}-\mathrm{C}_{16} \mathrm{H}_{26} \mathrm{O}_{2}$, respectively). Characteristic ions as $m / z 203\left([\mathrm{M}]^{+\bullet}-\mathrm{C}_{2} \mathrm{H}_{5}\right)$ and $m / z, 189$ 

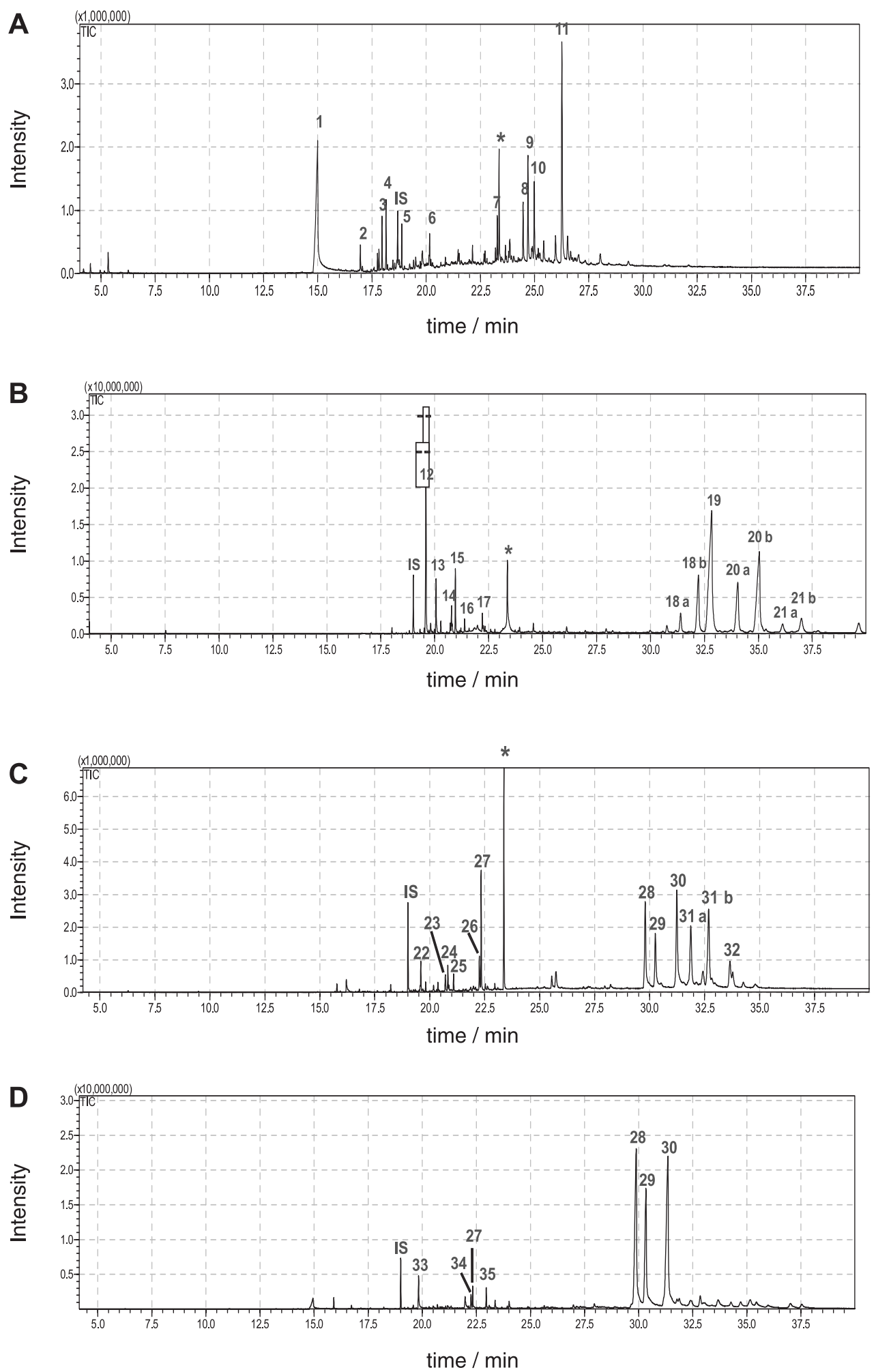

Figure 1. Total ion count mass spectrometry analysis of P. nemorosa leaves: (A) hexane; (B) hexane/EtOAc 5\% and (C and D) hexane/EtOAc 10\% fractions obtained by GC-MS. IS: Internal standard. *Plasticizer: bis-(2-ethylhexyl) phthalate.

$\left([\mathrm{M}]^{\bullet \cdot}-\mathrm{CH}_{3}\right)$, derived from the ions $m / z 218$, were also observed. A McLafferty rearrangement in $\alpha / \beta$-amyrin acetates $\left([\mathrm{M}]^{+\cdot}-\mathrm{C}_{2} \mathrm{H}_{4} \mathrm{O}_{2}\right)$ at $m / z 408$ was also seen. The same takes place with 3,11-dioxo- $\alpha / \beta$-amyrene $\left(\mathrm{m} / \mathrm{z}, 438,[\mathrm{M}]^{+*}\right)$, generating the characteristic fragments at $\mathrm{m} / \mathrm{z} 273\left([\mathrm{M}]^{+*}-\mathrm{C}_{11} \mathrm{H}_{17} \mathrm{O}\right), 232\left([\mathrm{M}]^{+*}-\mathrm{C}_{14} \mathrm{H}_{22} \mathrm{O}\right), 217$ $\left([\mathrm{M}]^{+*}-\mathrm{C}_{14} \mathrm{H}_{22} \mathrm{O}-\mathrm{CH}_{3}\right), 189\left([\mathrm{M}]^{+*}-\mathrm{C}_{14} \mathrm{H}_{22} \mathrm{O}-\mathrm{CH}_{3}-\mathrm{CO}\right)$ and $135\left([\mathrm{M}]^{+*}-\mathrm{C}_{11} \mathrm{H}_{17} \mathrm{O}-\mathrm{C}_{10} \mathrm{H}_{18}\right) .^{41}$ 
The mixture of $\alpha / \beta$-amyrin (31a, 31b), previously purified from Protium sp. resin, ${ }^{42}$ and lupeol (19), derived from Vellozia sp. ${ }^{43}$ were subjected to classic esterification and oxidation reactions to give derivatives in good yields (Schemes 1 and 2). These reference compounds were used in co-injection assays or for comparison of retention time as an additional tool to confirm GC-MS results (Supplementary Information).

As $\alpha$-amyrin acetate (20b) and lupeol acetate exhibit the same retention times in this condition (34.8 $\mathrm{min})$, the mass fragmentation profile was determined to confirm the presence of $\alpha$-amyrin acetate in fraction 5 (Supplementary Information).

Besides the triterpenes confirmation, GC-MS allowed us to detect a further series of hydrocarbons, long chain fatty acids and their esters.

Nowadays, ultra fast liquid chromatography/tandem mass spectrometry (UFLC-MS/MS) is one of the most convenient techniques for online characterization, due to its superior sensitivity, high selectivity, short run time and resolution power which allow direct screening of natural products. ${ }^{44}$ UFLC coupled to quadrupole-time-of-flight (Q-TOF) is widely applied in herb research and has brought a big convenience for qualitative analysis, allowing quick and effective data acquisition. In terms of the accurate mass measurement, it gives characteristic ions for the identification of molecular formula and the gas phase decomposition reactions activated by collision induction dissociation (CID) may furnish key information for a safe structural elucidation. ${ }^{45,46}$

The most polar fractions eluted with EtOAc and $\mathrm{MeOH}$ from the silica gel column chromatography of EE were analyzed by UFLC coupled with a Q-TOF and a quadrupole ion trap MS apparatus, to obtain high mass accuracy measurements of both parent and fragment ions, as also to deliver sufficient information to detect and reliably identify

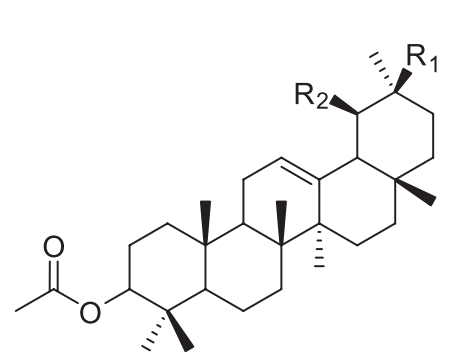

$(20 a, b)$

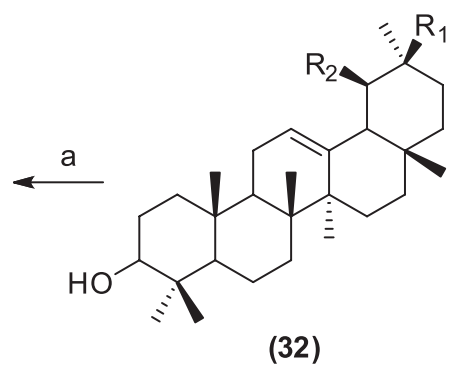

(31 a) $\beta-\mathrm{R}_{1}=\mathrm{CH}_{3}, \mathrm{R}_{2}=\mathrm{H}$ (31 b) $\alpha-\mathrm{R}_{1}=\mathrm{H}, \mathrm{R}_{2}=\mathrm{CH}_{3}$

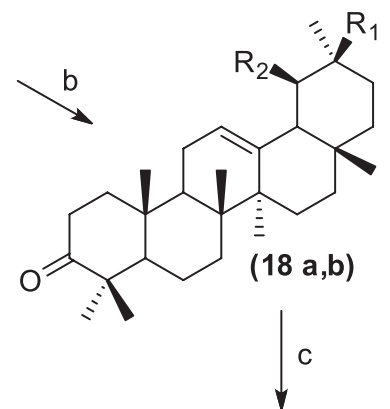

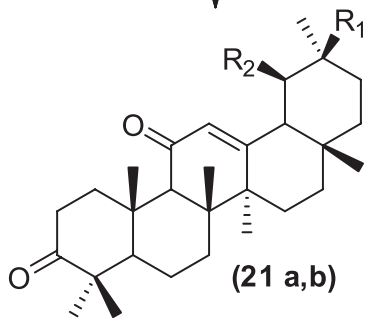

Scheme 1. (a) $\mathrm{Ac}_{2} \mathrm{O}$, DMAP, reflux, $2 \mathrm{~h}(98 \%)$; (b) Jones reagent, acetone (97\%); (c) di-tert-butyl chromate, Ac $2 \mathrm{O}, \mathrm{AcOH}$, acetone, reflux, 6 h ( $\left.88 \%\right)$. ${ }^{6-28}$

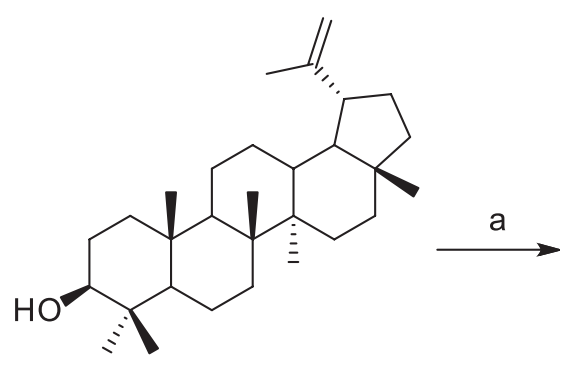

(19)<smiles>C=C(C)[C@H]1CC[C@]2(C)CC[C@]3(C)C(CCC4[C@H]3CC[C@@]3(C)[C@H](C)C(OC(C)=O)CC[C@]43C)C12</smiles>

Lupeol acetate 
compounds in this complex mixture. Tables 1 to 4 show retention times, formulae, UV features, compound names, mass spectrum features in both positive and negative ions modes, and fragment ions results produced by $\mathrm{MS}^{2}$.

In the EtOAc fraction, it was possible to identify some compounds previously described in other Psychotria species, such as: loliolide, in P. cadigensis ${ }^{47}$ and P. yunnanensis ${ }^{33}$ butin, also in P. yunnanensis ${ }^{33}$ epiloganin, as part of the alkaloid brachycerin in P. brachyceras ${ }^{48}$ and deacetylasperuloside, in P. leiocarpa. ${ }^{15}$ The fraction eluted with $\mathrm{MeOH}$ yielded rutin and kaempferol-7-Oglucopyranoside, as in $P$. haianensis, ${ }^{36}$ and epiloganin. Phenolic compounds closely related with syringol/vannilic alchool/hydroxytyrosol were described in P. yunnanensis. ${ }^{33}$

Characteristic UV spectra existed in different types of compounds, and can be an important tool to precisely identify isomers with distinguishable chromophores. Data from mass spectra, such as $[\mathrm{M}-\mathrm{H}]^{-},[\mathrm{M}+\mathrm{H}]^{+}$, $[\mathrm{M}+\mathrm{Na}]^{+},[\mathrm{M}+\mathrm{K}]^{+}$ions with their characteristic fragment ions reinforce identification. In our analyzes, butin $(\mathrm{m} / \mathrm{z}$ 273.1108, $[\mathrm{M}+\mathrm{H}]^{+}$) was detected in positive mode showing that loss of $\mathrm{H}_{2} \mathrm{O}\left(\mathrm{m} / \mathrm{z} 255.09\left[\mathrm{M}+\mathrm{H}-\mathrm{H}_{2} \mathrm{O}\right]^{+}\right)$ is characteristic of two $\mathrm{OH}$ groups in ortho. Ions at $\mathrm{m} / \mathrm{z}$ $245.05[\mathrm{M}+\mathrm{H}-\mathrm{CO}]^{+}$and $m / z 229.08\left[\mathrm{M}+\mathrm{H}-\mathrm{CO}_{2}\right]^{+}$ were observed, consistent with the literature. ${ }^{49} \mathrm{MS}$ and UV data are according to literature ${ }^{50,51}$ (Table 1). Loliolide $\left(m / z\right.$ 197.1163, $\left.[\mathrm{M}+\mathrm{H}]^{+}\right)$was identified by comparison of its mass spectra with previously reported values. Strong UV-Vis absorption at $218 \mathrm{~nm}$ suggested an $\alpha-\beta$ unsaturated ester/lactone. ${ }^{52}$ Ions at $m / z 179.06$ and $m / z 111.92$ confirmed the loss of $\mathrm{H}_{2} \mathrm{O}\left[\mathrm{M}+\mathrm{H}-\mathrm{H}_{2} \mathrm{O}\right]^{+}$, and also the loss of the ring adjacent to the lactone $\left[\mathrm{M}+\mathrm{H}-\mathrm{H}_{2} \mathrm{O}-\mathrm{C}_{5} \mathrm{H}_{8}\right]^{+}$(Table 1).

The ion at $m / z 385.1258[\mathrm{M}+\mathrm{Na}]^{+}$was related to a gibberellin nucleus, with a fragmentation similar to that reported by Takahashi et al. ${ }^{53}$ The ions at $\mathrm{m} / \mathrm{z} 316.2820$ $[\mathrm{M}+\mathrm{H}]^{+}$and $m / z, 318.2974[\mathrm{M}+\mathrm{H}]^{+}$led to the identication of dehydrophytosphingosine and phytosphingosine, respectively, according to the literature. ${ }^{54,55}$ The ceramide 2-amino-1,3,4-docosanetriol $\left(\mathrm{m} / \mathrm{z}, 412.3161,[\mathrm{M}+\mathrm{K}]^{+}\right)$ and 2-palmitoylglycerol $\left(\mathrm{m} / \mathrm{z}, 353.2645,[\mathrm{M}+\mathrm{Na}]^{+}\right)$, a glycerolipid, were observed. The mass spectra data are in agreement with previous reports ${ }^{56,57}$ (Table 1).

The ESI-MS spectra (negative ion mode) of fraction EtOAc (Table 2) revealed 7-epiloganin, resveratrol, deacetylasperuloside, ferulic and azelaic acids. Based on the fragmentation characteristics of iridoid- $O$ glycosides, the assignment of 7-epiloganin $(\mathrm{m} / \mathrm{z} 389.1169$, $[\mathrm{M}-\mathrm{H}]^{-}$) was consistent with fragments at $m / z 357.20$ and $m / z 226.95$ in the MS/MS spectrum, due to the loss of methoxy group and glucose moiety from the precursor ion, respectively. Elimination of methyl ester from $m / z, 226.95\left[\mathrm{M}-\mathrm{H}-\mathrm{C}_{2} \mathrm{H}_{4} \mathrm{O}_{2}\right]^{-}$with subsequent dehydration showed the major product ion at $\mathrm{m} / \mathrm{z} 151.11$ $\left[\mathrm{M}-\mathrm{H}-\mathrm{C}_{2} \mathrm{H}_{4} \mathrm{O}_{2}-\mathrm{H}_{2} \mathrm{O}\right]^{-.58,59}$ The UV spectrum and fragmentation patterns of $[\mathrm{M}-\mathrm{H}]^{-}$of resveratrol $(\mathrm{m} / \mathrm{z}, 227.0646)$ is consistent with previous reports. ${ }^{60,61}$ The fragment ion at $m / z, 185.05[\mathrm{M}-\mathrm{H}-\mathrm{CHCOH}]^{-}$corresponds to a loss of $42 \mathrm{Da}$ with $\mathrm{H}$ rearrangement from the precursor ion $\left(m / z\right.$ 227.0646). The ions at $m / z 159.08\left[\mathrm{M}-\mathrm{H}-\mathrm{C}_{3} \mathrm{O}_{2}\right]^{-}$ and $m / z, 183.18\left[\mathrm{M}-\mathrm{H}-\mathrm{CO}_{2}\right]^{-}$were formed by a cyclization reaction of the precursor ion with loss of $\mathrm{C}_{3} \mathrm{O}_{2}$ and $\mathrm{OH}$ rearrangement with loss of $\mathrm{CO}_{2}$, respectively.

Based on literature published data, the presence of deacetylasperuloside $\left(\mathrm{m} / \mathrm{z}, 371.0950[\mathrm{M}-\mathrm{H}]^{-}\right)$was suggested by the following ions: $m / z 353.04\left[\mathrm{M}-\mathrm{H}-\mathrm{H}_{2} \mathrm{O}\right]^{-}, m / z$ $209.06\left[\mathrm{M}-\mathrm{H}-\mathrm{Glc}^{-}, \mathrm{m} / z .165 .06\left[\mathrm{M}-\mathrm{H}-\mathrm{Glc}-\mathrm{CO}_{2}\right]^{-}\right.$ and $m / z$ 147.05 [M - $\left.\mathrm{H}-\mathrm{Glc}-\mathrm{CO}_{2}-\mathrm{H}_{2} \mathrm{O}\right]^{-62,63}$

Ferulic acid was identified through the deprotonated molecule $[\mathrm{M}-\mathrm{H}]^{-}(\mathrm{m} / \mathrm{z}$ 193.0458) that gave the major fragment ion at $m / z, 148.92\left[\mathrm{M}-\mathrm{H}-\mathrm{CO}_{2}\right]^{-}$. Other fragments were at $m / z 178.08\left[\mathrm{M}-\mathrm{H}-\mathrm{CH}_{3}\right]^{-}$and $\mathrm{m} / z 134.12$ $\left[\mathrm{M}-\mathrm{H}-\mathrm{CH}_{3}-\mathrm{CO}_{2}\right]^{-64,65}$ The UV values correspond to this phenolic compound. ${ }^{66}$

The deprotonated molecule at $m / z$ 187.0930 [M - H] ${ }^{-}$ for azelaic acid produced the fragment ions at $\mathrm{m} / \mathrm{z}: 169.03$ $\left[\mathrm{M}-\mathrm{H}-\mathrm{H}_{2} \mathrm{O}\right]^{-}, 143.10\left[\mathrm{M}-\mathrm{H}-\mathrm{CO}_{2}\right]^{-}$and 124.98 $\left[\mathrm{M}-\mathrm{H}-\mathrm{CO}_{2}-\mathrm{H}_{2} \mathrm{O}\right]^{-}$according to mass bank record and UV spectrum. ${ }^{67,68}$

In the polar fraction eluted with $\mathrm{MeOH}$ it was detected hordenine, eusterol, 8-amino-7-oxononanoic acid, syringol/vanillic alchool/hydroxytyrosol, stryctosidine, $N$-methyl-1,2,3,4-tetrahydro- $\beta$-carboline and a pyrogallol related compound, in positive mode. 7-Epiloganin, rutin, kaempferol 7-O- $\beta$-D-glucopyranoside and $\mathrm{N}$-formyltryptamine were identified in the negative mode (Tables 3 and 4). The alkaloids stryctosidine, $N$-methyl-1,2,3,4tetrahydro- $\beta$-carboline and the flavonoids rutin and kaempferol 7-O- $\beta$-D-glucopyranoside have been reported in other Psychotria species..$^{36,69,70}$

Hordenine yielded $[\mathrm{M}+\mathrm{H}]^{+}$at $\mathrm{m} / z, 166.1215$ and a major fragment at $m / z$ 121.01 $\left[\mathrm{M}+\mathrm{H}-\mathrm{HN}\left(\mathrm{CH}_{3}\right)_{2}\right]^{+}$, which then loses $\mathrm{H}_{2} \mathrm{O}$ yielding an ion at $\mathrm{m} / \mathrm{z} 103.07$ $\left[\mathrm{M}+\mathrm{H}-\mathrm{HN}\left(\mathrm{CH}_{3}\right)_{2}-\mathrm{H}_{2} \mathrm{O}\right]^{+}$. Stryctosidine, already reported in genus Psychotria, was detected as $[\mathrm{M}+\mathrm{H}]^{+}$ at $m / z$ 531.2283, that loses $\mathrm{OH}[\mathrm{M}+\mathrm{H}-\mathrm{OH}]^{+}$yielding a fragment at $m / z 514.19$ and at $m / z, 369.17$, due to loss of the sugar moiety $[\mathrm{M}+\mathrm{H}-\mathrm{Glc}]^{+} .^{71}$ The alkaloid $N$-methyl1,2,3,4-tetrahydro- $\beta$-carboline $[\mathrm{M}+\mathrm{H}]^{+}$at $\mathrm{m} / z 187.1226$ yielded ions at $\mathrm{m} / \mathrm{z}, 158.09$ and $\mathrm{m} / \mathrm{z} 144.16$ due to loss of $\mathrm{CH}_{3} \mathrm{~N}\left[\mathrm{M}+\mathrm{H}-\mathrm{CH}_{3} \mathrm{~N}\right]^{+}$and $\mathrm{C}_{2} \mathrm{H}_{5} \mathrm{~N}\left[\mathrm{M}+\mathrm{H}-\mathrm{C}_{2} \mathrm{H}_{5} \mathrm{~N}\right]^{+}$ fragments, respectively. ${ }^{72}$ 
The flavonoid rutin was detected as the deprotonated molecule $[\mathrm{M}-\mathrm{H}]^{-}$at $\mathrm{m} / \mathrm{z}$ 609.1453. The fragment ions, resulting from the cleavage of the glycosidic bond with the loss of $308 \mathrm{Da}$ corresponds to a rhamnose (146 Da) plus a glucose (162 Da) moiety followed by loss of $\mathrm{CH}_{2} \mathrm{O}$ fragment, at $m / z 301.06[\mathrm{M}-\mathrm{H}-\mathrm{Rham}-\mathrm{Glc}]^{-}$and 271.10 $\left[\mathrm{M}-\mathrm{H}-\mathrm{Rham}-\mathrm{Glc}-\mathrm{CH}_{2} \mathrm{O}\right]^{-}$, respectively. All spectral data, mass and UV, are in according to Tiberti et al. ${ }^{73}$ and Lopes-Lutz et al. ${ }^{74}$ The molecular formula $\mathrm{C}_{21} \mathrm{H}_{20} \mathrm{O}_{11}$ $\left([\mathrm{M}-\mathrm{H}]^{-}\right.$at $m / z$ 447.1827) was associated to kaempferol 7-O- $\beta$-D-glucopyranoside, that gave an ion at $\mathrm{m} / \mathrm{z} 285.08$ $[\mathrm{M}-\mathrm{H}-\mathrm{Glc}]^{-}$due to known $O$-glucosides fragmentation pattern. ${ }^{75}$ Consistent with the UV spectra and fragmentation behavior, a homolytic cleavage is observed, generating an aglycone ion at $m / z 284.13 .^{76}$

The alkaloid $\mathrm{N}$-formyl tryptamine was detected in negative mode $\left([\mathrm{M}-\mathrm{H}]^{-}\right.$at $m / z$ 187.0934) and exhibited two fragments: one major at $\mathrm{m} / \mathrm{z} 159.05$ due the loss of
$\mathrm{CO}$ moiety $\left[\mathrm{M}-\mathrm{H}-\mathrm{CO}^{-}\right.$, and other at $\mathrm{m} / \mathrm{z} 130.11$ after a supposing loss of $\mathrm{CHNH}_{2}\left[\mathrm{M}-\mathrm{H}-\mathrm{CHNH}_{2}\right]^{-}$.

The occurrence of hordenine, resveratrol and ferulic acid are being reported for the first time in Psychotria genus.

This preliminary phytochemical screening by GC-MS and LC-MS proved to be an useful tool to identify secondary metabolites from $P$. nemorosa leaves, both polar and nonpolar bioactive compounds successfully mapped (Figure 2).

\section{Antinociceptive activity}

As shown in Figure 3, the EE of P. nemorosa leaves exhibited a signicant antinociceptive activity on formalininduced licking response test in mice, but the EE from branches did not (data not shown). The injection of formalin $(2.5 \%)$ leads to a biphasic licking response of the injected

Table 1. Characterization of the chemical composition of EtOAc fraction of $P$. nemorosa leaves by UFLC-DAD-ESI-MS ${ }^{2}$ in positive mode

\begin{tabular}{|c|c|c|c|c|c|c|c|c|c|}
\hline Peak & $\mathrm{R}_{\mathrm{t}} / \min$ & $\begin{array}{c}m / z \\
\text { experimental }\end{array}$ & $\begin{array}{c}m / z \\
\text { calculated }\end{array}$ & $\begin{array}{l}\text { Error } \\
{[\mathrm{ppm}]}\end{array}$ & $\begin{array}{c}\text { Protonated } \\
\text { molecule }[\mathrm{M}]^{+}\end{array}$ & $\begin{array}{c}\text { Molecular } \\
\text { formula }\end{array}$ & $\begin{array}{l}\text { MS/MS } \\
\text { fragments }\end{array}$ & $\lambda_{\max } / \mathrm{nm}$ & Proposed compound \\
\hline 36 & 14.8 & 273.1108 & 273.1112 & -1.5 & {$[\mathrm{M}+\mathrm{H}]^{+}$} & $\mathrm{C}_{15} \mathrm{H}_{12} \mathrm{O}_{5}$ & $255,245,229$ & $274 ; 318$ & butin \\
\hline 37 & 16.8 & 197.1163 & 197.1172 & 4.6 & {$[\mathrm{M}+\mathrm{H}]^{+}$} & $\mathrm{C}_{11} \mathrm{H}_{16} \mathrm{O}_{3}$ & $179,164,112$ & 217 & loliolide \\
\hline 38 & 19.9 & 385.1259 & 385.1258 & 0.4 & {$[\mathrm{M}+\mathrm{Na}]^{+}$} & $\mathrm{C}_{19} \mathrm{H}_{22} \mathrm{O}_{7}$ & $353,327,309$ & 210 & gibberellin related compound \\
\hline 39 & 25.4 & 316.2820 & 316.2842 & -8.2 & {$[\mathrm{M}+\mathrm{H}]^{+}$} & $\mathrm{C}_{18} \mathrm{H}_{37} \mathrm{NO}_{3}$ & $298,280,250$ & 223 & dehydrophytosphingosine \\
\hline 40 & 26.5 & 318.2974 & 318.3003 & 9.1 & {$[\mathrm{M}+\mathrm{H}]^{+}$} & $\mathrm{C}_{18} \mathrm{H}_{39} \mathrm{NO}_{3}$ & $300,282,265$ & 223 & phytosphingosine \\
\hline 41 & 28.9 & 412.3161 & 412.3188 & 6.4 & {$[\mathrm{M}+\mathrm{K}]^{+}$} & $\mathrm{C}_{22} \mathrm{H}_{47} \mathrm{NO}_{3}$ & $394,376,346$ & 223 & 2-amino-1,3,4-docosanetriol \\
\hline 42 & 31.8 & 353.2645 & 353.2662 & -5.0 & {$[\mathrm{M}+\mathrm{Na}]^{+}$} & $\mathrm{C}_{19} \mathrm{H}_{38} \mathrm{O}_{4}$ & $335,262,248$ & 224 & 2-palmitoylglycerol \\
\hline 43 & 34.4 & 629.3601 & 629.3601 & 0 & {$[\mathrm{M}+\mathrm{Na}]^{+}$} & $\mathrm{C}_{41} \mathrm{H}_{50} \mathrm{O}_{4}$ & $611,447,429$ & 223 & n.i. \\
\hline
\end{tabular}

n.i.: not identified.

Table 2. Characterization of the chemical composition of EtOAc fraction of P. nemorosa leaves by UFLC-DAD-ESI-MS ${ }^{2}$ in negative mode

\begin{tabular}{|c|c|c|c|c|c|c|c|c|c|}
\hline Peak & $\mathrm{R}_{\mathrm{t}} / \min$ & $\begin{array}{c}m / z \\
\text { experimental }\end{array}$ & $\begin{array}{c}m / z \\
\text { calculated }\end{array}$ & $\begin{array}{c}\text { Error } \\
\text { [ppm] }\end{array}$ & $\begin{array}{c}\text { Deprotonated } \\
\text { molecule }[\mathrm{M}]^{-}\end{array}$ & $\begin{array}{l}\text { Molecular } \\
\text { formula }\end{array}$ & $\begin{array}{l}\text { MS/MS } \\
\text { fragments }\end{array}$ & $\lambda_{\max } / \mathrm{nm}$ & Proposed compound \\
\hline 44 & 6.5 & 389.1169 & 389.1175 & 1.6 & {$[\mathrm{M}-\mathrm{H}]^{-}$} & $\mathrm{C}_{17} \mathrm{H}_{26} \mathrm{O}_{10}$ & $357,227,169,151$ & 235 & 7-epiloganin \\
\hline 45 & 7.6 & 227.0646 & 227.0647 & 0.1 & {$[\mathrm{M}-\mathrm{H}]^{-}$} & $\mathrm{C}_{14} \mathrm{H}_{12} \mathrm{O}_{3}$ & $185,183,159$ & $279 ; 305$ & resveratrol \\
\hline 46 & 9.5 & 379.0677 & 379.0671 & -1.8 & {$[\mathrm{M}-\mathrm{H}]^{-}$} & $\mathrm{C}_{17} \mathrm{H}_{16} \mathrm{O}_{10}$ & $333,249,161$ & 208 & n.i. \\
\hline 47 & 12.1 & 431.1885 & 431.1896 & 2.5 & {$[\mathrm{M}+\mathrm{Cl}]^{-}$} & $\mathrm{C}_{21} \mathrm{H}_{32} \mathrm{O}_{7}$ & $385,223,161$ & 213 & n.i. \\
\hline 48 & 13.6 & 371.0950 & 371.0984 & 9.1 & {$[\mathrm{M}-\mathrm{H}]^{-}$} & $\mathrm{C}_{16} \mathrm{H}_{20} \mathrm{O}_{10}$ & $353,209,165,147$ & 233 & deacetylasperuloside \\
\hline 49 & 14.2 & 475.1759 & 475.1762 & 0.8 & {$[\mathrm{M}-\mathrm{H}]^{-}$} & $\mathrm{C}_{28} \mathrm{H}_{28} \mathrm{O}_{7}$ & $429,289,235,163$ & 218 & n.i. \\
\hline 50 & 15.3 & 363.0713 & 363.0722 & 2.2 & {$[\mathrm{M}-\mathrm{H}]^{-}$} & $\mathrm{C}_{17} \mathrm{H}_{16} \mathrm{O}_{9}$ & $317,267,241$ & 220 & n.i. \\
\hline 51 & 15.9 & 193.0458 & 193.0506 & -25.0 & {$[\mathrm{M}-\mathrm{H}]^{-}$} & $\mathrm{C}_{10} \mathrm{H}_{10} \mathrm{O}_{4}$ & $178,149,134$ & $285 ; 322$ & ferulic acid \\
\hline 52 & 17.7 & 187.0930 & 187.0976 & -24.7 & {$[\mathrm{M}-\mathrm{H}]^{-}$} & $\mathrm{C}_{9} \mathrm{H}_{16} \mathrm{O}_{4}$ & $169,143,125$ & 205 & azelaic acid \\
\hline 53 & 18.9 & 401.1200 & 401.1220 & -5.0 & {$[\mathrm{M}+\mathrm{Cl}]^{-}$} & $\mathrm{C}_{15} \mathrm{H}_{26} \mathrm{O}_{10}$ & $369,325,193$ & 220 & n.i. \\
\hline 54 & 32.4 & 721.3543 & 721.3526 & 2.4 & {$[\mathrm{M}-\mathrm{H}]^{-}$} & $\mathrm{C}_{41} \mathrm{H}_{54} \mathrm{O}_{11}$ & 675,397 & 224 & n.i. \\
\hline 55 & 36.5 & 559.3058 & 559.3065 & -1.2 & {$[\mathrm{M}-\mathrm{H}]^{-}$} & $\mathrm{C}_{35} \mathrm{H}_{44} \mathrm{O}_{6}$ & $513,379,277$ & 230 & n.i. \\
\hline
\end{tabular}

n.i.: not identified. 
Table 3. Characterization of the chemical composition of $\mathrm{MeOH}$ fraction of $P$. nemorosa leaves by UFLC-DAD-ESI-MS ${ }^{2}$ in positive mode

\begin{tabular}{|c|c|c|c|c|c|c|c|c|c|}
\hline Peak & $\mathrm{R}_{\mathrm{t}} / \min$ & $\begin{array}{c}m / z \\
\text { experimental }\end{array}$ & $\begin{array}{c}m / z \\
\text { calculated }\end{array}$ & $\begin{array}{l}\text { Error } \\
{[\mathrm{ppm}]}\end{array}$ & $\begin{array}{c}\text { Protonated } \\
\text { molecule }[\mathrm{M}]^{+}\end{array}$ & $\begin{array}{c}\text { Molecular } \\
\text { formula }\end{array}$ & $\begin{array}{c}\text { MS/MS } \\
\text { fragments }\end{array}$ & $\begin{array}{c}\lambda_{\max } / \\
\mathrm{nm}\end{array}$ & Proposed compound \\
\hline 56 & 3.2 & 166.1215 & 166.1226 & -7.2 & {$[\mathrm{M}+\mathrm{H}]^{+}$} & $\mathrm{C}_{10} \mathrm{H}_{15} \mathrm{NO}$ & $121,103,91$ & 278 & hordenine \\
\hline 57 & 4.4 & 328.1719 & 328.1731 & -3.6 & {$[\mathrm{M}+\mathrm{Na}]^{+}$} & $\mathrm{C}_{14} \mathrm{H}_{27} \mathrm{NO}_{6}$ & 166,121 & - & n.i. \\
\hline 58 & 6.0 & 164.1054 & 164.1046 & 4.7 & {$[\mathrm{M}+\mathrm{H}]^{+}$} & $\mathrm{C}_{10} \mathrm{H}_{13} \mathrm{NO}$ & $147,119,91$ & 260 & eusterol \\
\hline 59 & 6.4 & 310.1254 & 310.1261 & 2.3 & {$[\mathrm{M}+\mathrm{Na}]^{+}$} & $\mathrm{C}_{13} \mathrm{H}_{21} \mathrm{NO}_{6}$ & $292,264,166$ & 206 & n.i. \\
\hline 60 & 6.8 & 210.1111 & 210.1101 & -4.9 & {$[\mathrm{M}+\mathrm{Na}]^{+}$} & $\mathrm{C}_{9} \mathrm{H}_{17} \mathrm{NO}_{3}$ & 192,166 & 215 & 8-amino-7-oxononanoic acid \\
\hline 61 & 8.0 & 244.0309 & 244.0330 & 8.5 & {$[\mathrm{M}+\mathrm{K}]^{+}$} & $\mathrm{C}_{6} \mathrm{H}_{11} \mathrm{~N}_{3} \mathrm{O}_{5}$ & 205,202 & 202 & sugar containing azide \\
\hline 62 & 8.5 & 360.1757 & 360.1765 & 2.3 & {$[\mathrm{M}+\mathrm{H}]^{+}$} & $\mathrm{C}_{15} \mathrm{H}_{25} \mathrm{~N}_{3} \mathrm{O}_{7}$ & $315,297,191$ & 202 & n.i. \\
\hline 63 & 11.2 & 177.0533 & 177.0546 & 7.2 & {$[\mathrm{M}+\mathrm{Na}]^{+}$} & $\mathrm{C}_{8} \mathrm{H}_{10} \mathrm{O}_{3}$ & 145,159 & $229 ; 282$ & $\begin{array}{l}\text { syringol/vanillic alcohol/ } \\
\text { hydroxytyrosol }\end{array}$ \\
\hline 64 & 11.5 & 207.1367 & 207.1356 & -5.4 & {$[\mathrm{M}+\mathrm{Na}]^{+}$} & $\mathrm{C}_{11} \mathrm{H}_{20} \mathrm{O}_{2}$ & $190,152,139$ & 209 & n.i. \\
\hline 65 & 11.8 & 374.1917 & 374.1922 & -1.1 & {$[\mathrm{M}+\mathrm{H}]^{+}$} & $\mathrm{C}_{16} \mathrm{H}_{27} \mathrm{~N}_{3} \mathrm{O}_{7}$ & $329,297,209,173$ & 214 & n.i. \\
\hline 66 & 14.1 & 531.2283 & 531.2313 & 5.7 & {$[\mathrm{M}+\mathrm{H}]^{+}$} & $\mathrm{C}_{27} \mathrm{H}_{34} \mathrm{~N}_{2} \mathrm{O}_{9}$ & 514,369 & 217 & stryctosidine \\
\hline 67 & 16.6 & 261.1085 & 261.1081 & 1.7 & {$[\mathrm{M}+\mathrm{H}]^{+}$} & $\mathrm{C}_{10} \mathrm{H}_{16} \mathrm{~N}_{2} \mathrm{O}_{6}$ & $243,201,177$ & 219 & n.i. \\
\hline 68 & 17.5 & 461.1913 & 461.1918 & -1.1 & {$[\mathrm{M}+\mathrm{H}]^{+}$} & $\mathrm{C}_{23} \mathrm{H}_{28} \mathrm{~N}_{2} \mathrm{O}_{8}$ & $371,299,158$ & 219 & n.i. \\
\hline 69 & 18.6 & 187.1226 & 187.1233 & 2.2 & {$[\mathrm{M}+\mathrm{H}]^{+}$} & $\mathrm{C}_{12} \mathrm{H}_{14} \mathrm{~N}_{2}$ & 158,144 & 219 & $\begin{array}{c}N \text {-methyl-1,2,3,4-tetrahydro- } \\
\beta \text {-carboline }\end{array}$ \\
\hline 70 & 20.4 & 149.0207 & 149.0209 & 1.8 & {$[\mathrm{M}+\mathrm{Na}]^{+}$} & $\mathrm{C}_{6} \mathrm{H}_{6} \mathrm{O}_{3}$ & 132,131 & 275 & pyrogallol related compound \\
\hline
\end{tabular}

Table 4. Characterization of the chemical composition of $\mathrm{MeOH}$ fraction of $P$. nemorosa leaves by UFLC-DAD-ESI-MS ${ }^{2}$ in negative mode

\begin{tabular}{|c|c|c|c|c|c|c|c|c|c|}
\hline Peak & $\mathrm{R}_{\mathrm{t}} / \min$ & $\begin{array}{c}m / z \\
\text { experimental }\end{array}$ & $\begin{array}{c}m / z \\
\text { calculated }\end{array}$ & $\begin{array}{l}\text { Error } \\
{[\mathrm{ppm}]}\end{array}$ & $\begin{array}{l}\text { Deprotonated } \\
\text { molecule }[\mathrm{M}]^{-}\end{array}$ & $\begin{array}{l}\text { Molecular } \\
\text { formula }\end{array}$ & $\begin{array}{l}\text { MS-MS } \\
\text { fragments }\end{array}$ & $\begin{array}{c}\lambda_{\max } / \\
\mathrm{nm}\end{array}$ & Proposed compound \\
\hline 71 & 3.1 & 361.0893 & 361.0907 & 3.9 & {$[\mathrm{M}+\mathrm{Cl}]^{-}$} & $\mathrm{C}_{12} \mathrm{H}_{22} \mathrm{O}_{10}$ & $325,265,163$ & - & n.i. \\
\hline 72 & 5.4 & 385.1311 & 385.1293 & -4.8 & {$[\mathrm{M}-\mathrm{H}]^{-}$} & $\mathrm{C}_{21} \mathrm{H}_{22} \mathrm{O}_{7}$ & 339,307 & - & n.i. \\
\hline 73 & 6.6 & 435.1216 & 435.1216 & -0.1 & {$\left[\mathrm{M}+\mathrm{Cl}^{-}\right.$} & $\mathrm{C}_{22} \mathrm{H}_{24} \mathrm{O}_{7}$ & 389 & 205 & n.i. \\
\hline 44 & 7.0 & 389.1175 & 389.1168 & -3.5 & {$[\mathrm{M}-\mathrm{H}]^{-}$} & $\mathrm{C}_{17} \mathrm{H}_{26} \mathrm{O}_{10}$ & $\begin{array}{c}357,227,169 \\
151\end{array}$ & 235 & 7-epiloganin \\
\hline 74 & 9.0 & 609.1453 & 609.1469 & -2.1 & {$[\mathrm{M}-\mathrm{H}]^{-}$} & $\mathrm{C}_{27} \mathrm{H}_{30} \mathrm{O}_{16}$ & $301,271,179$ & $258 ; 357$ & rutin \\
\hline 75 & 9.5 & 447.1827 & 447.1832 & -0.9 & {$[\mathrm{M}-\mathrm{H}]^{-}$} & $\mathrm{C}_{21} \mathrm{H}_{20} \mathrm{O}_{11}$ & $325,285,284$ & $228 ; 284 ; 349$ & $\begin{array}{l}\text { kaempferol 7-O- } \beta \text {-D- } \\
\text { glucopyranoside }\end{array}$ \\
\hline 76 & 12.1 & 501.1568 & 501.1573 & -1.0 & {$[\mathrm{M}-\mathrm{H}]^{-}$} & $\mathrm{C}_{17} \mathrm{H}_{30} \mathrm{~N}_{2} \mathrm{O}_{15}$ & $\begin{array}{c}483,441,307, \\
217\end{array}$ & 205 & n.i. \\
\hline 77 & 12.5 & 449.1985 & 449.1988 & 0.8 & {$[\mathrm{M}-\mathrm{H}]^{-}$} & $\mathrm{C}_{15} \mathrm{H}_{34} \mathrm{~N}_{2} \mathrm{O}_{13}$ & $403,319,283$ & 212 & n.i. \\
\hline 78 & 13.4 & 695.2114 & 695.2134 & -2.9 & {$[\mathrm{M}-\mathrm{H}]^{-}$} & $\mathrm{C}_{39} \mathrm{H}_{36} \mathrm{O}_{12}$ & $\begin{array}{l}635,532,429 \\
387,325,235\end{array}$ & 216 & n.i. \\
\hline 79 & 15.5 & 387.1059 & 387.1045 & 3.5 & {$[\mathrm{M}-\mathrm{H}]^{-}$} & $\mathrm{C}_{15} \mathrm{H}_{20} \mathrm{~N}_{2} \mathrm{O}_{10}$ & $\begin{array}{c}369,343,284 \\
193\end{array}$ & 217 & n.i. \\
\hline 80 & 18.1 & 187.0934 & 187.0949 & 7.9 & {$[\mathrm{M}-\mathrm{H}]^{-}$} & $\mathrm{C}_{11} \mathrm{H}_{12} \mathrm{~N}_{2} \mathrm{O}$ & 159,130 & $230 ; 290$ & $\mathrm{~N}$-formyl-tryptamine \\
\hline 81 & 20.7 & 401.1213 & 401.1202 & 1.9 & {$[\mathrm{M}-\mathrm{H}]^{-}$} & $\mathrm{C}_{16} \mathrm{H} 22 \mathrm{~N}_{2} \mathrm{O}_{10}$ & $369,325,282$ & 220 & n.i. \\
\hline
\end{tabular}

paw. The first phase lasts until 5 min after injection due to a direct stimulation of nociceptors, and the second phase occurs between 15 and 30 min after formalin injection due to a combination of an inflammatory reaction in the peripheral tissue and changes in central processing. ${ }^{31}$
The anti-inflammatory non-steroidal drug acetylsalicylic acid (ASA) reduced the time by $13.0 \%$ and the opioid analgesic morphine by $44.8 \%$. Ethanol extract (EE) inhibited in $64.4,62.5$ and $67.2 \%$ the licking time at the doses of 10, 30, and $100 \mathrm{mg} \mathrm{kg}^{-1}$, respectively (Figure 3), 
<smiles>O=C(O)/C=C/c1ccccc1</smiles>

(1)<smiles>CC(=O)/C=C/C1=C(C)C(O)CCC1(C)C</smiles>

(5)<smiles>CC(=CCO)CCCC(C)CCCC(C)CCCC(C)C</smiles>

(6)<smiles>CCOC(=O)CCCCCCCCCCCC(C)C</smiles>

(13)<smiles>[R1]CCCCCCC(=O)O[R]</smiles>

(15) $\mathrm{R}_{1}=\mathrm{C}_{11} \mathrm{H}_{23}, \mathrm{R}_{2}=\mathrm{CH}_{3}$

(16) $\mathrm{R}_{1}=\mathrm{C}_{11} \mathrm{H}_{23}, \mathrm{R}_{2}=\mathrm{C}_{2} \mathrm{H}_{5}$

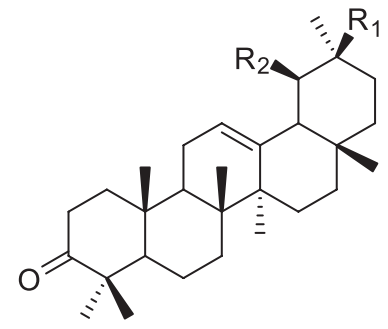

(18a) $\beta-\mathrm{R}_{1}=\mathrm{CH}_{3}, \mathrm{R}_{2}=\mathrm{H}$

(18b) $\alpha-\mathrm{R}_{1}=\mathrm{H}, \mathrm{R}_{2}=\mathrm{CH}_{3}$<smiles>C=C(C)[C@@H]1CC[C@]2(C)CC[C@]3(C)C(CCC4[C@@]5(C)CC[C@@H](O)C(C)(C)C5CC[C@]43C)C12</smiles>

(19)<smiles>CC1(C)CCCC2(C)OC(=O)C=C12</smiles>

(3)<smiles>[R]CCCCCCCC</smiles>

(4) $\mathrm{R}=\mathrm{C}_{8} \mathrm{H}_{16} \mathrm{Cl}$

(7) $\mathrm{R}=\mathrm{C}_{16} \mathrm{H}_{33}$

(8) $\mathrm{R}=\mathrm{C}_{20} \mathrm{H}_{41}$

(9) $\mathrm{R}=\mathrm{C}_{21} \mathrm{H}_{43}$

(10) $\mathrm{R}=\mathrm{C}_{20} \mathrm{H}_{41}$

(11) $\mathrm{R}=\mathrm{C}_{22} \mathrm{H}_{45}$

(22) $\mathrm{R}=\mathrm{C}_{19} \mathrm{H}_{39} \mathrm{O}$

(33) $\mathrm{R}=\mathrm{C}_{8} \mathrm{H}_{15} \mathrm{O}_{2}$
(12)<smiles>C=CC(C)(O)CCCC(C)CCCC(C)CCCC(C)C</smiles><smiles>CCCCCC/C=C/C/C=C/CCCCCCC(=O)OC</smiles>

(14)<smiles>COC(=O)CCCCCCCCCCCCCCCCC(C)C</smiles>

(17)

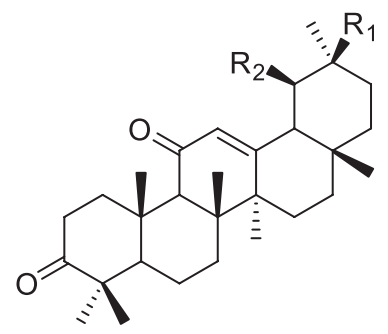<smiles>[R]CCOC(=O)C(=O)OCCCCCC</smiles>

(23) $\mathrm{R}=\mathrm{C}_{15} \mathrm{H}_{31}$<smiles>[R]CCOC(=O)C(=O)OCCCC(C)C</smiles>

(21a) $\beta-\mathrm{R}_{1}=\mathrm{CH}_{3}, \mathrm{R}_{2}=\mathrm{H}$ (21b) $\alpha-\mathrm{R}_{1}=\mathrm{H}, \mathrm{R}_{2}=\mathrm{CH}_{3}$<smiles>CC(C)CCCCCC1C=CC(=O)O1</smiles>

(24) $\mathrm{R}=\mathrm{C}_{14} \mathrm{H}_{29}$ 
<smiles>CC(C)CCCC(C)CCCC(C)CCCC1(C)CCC(=O)O1</smiles>

(28)

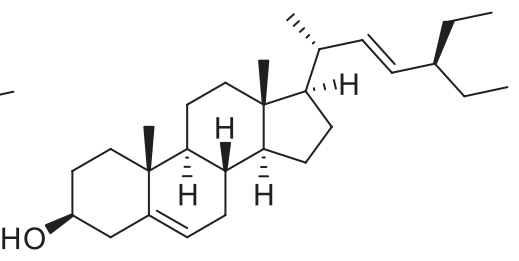

(29)<smiles>CC[C@H](CC[C@@H](C)[C@H]1CC[C@H]2[C@@H]3CC=C4C[C@@H](O)CC[C@]4(C)[C@H]3CC[C@@]21C)C(C)C</smiles>

(30)

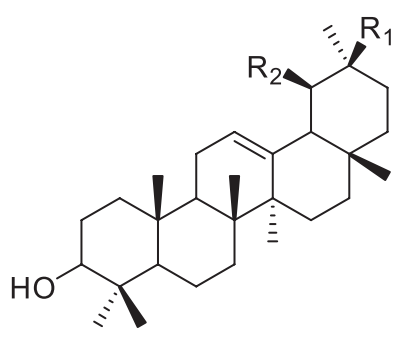

(31a) $\beta-\mathrm{R}_{1}=\mathrm{CH}_{3}, \mathrm{R}_{2}=\mathrm{H}$ (31b) $\alpha-\mathrm{R}_{1}=\mathrm{H}, \mathrm{R}_{2}=\mathrm{CH}_{3}$

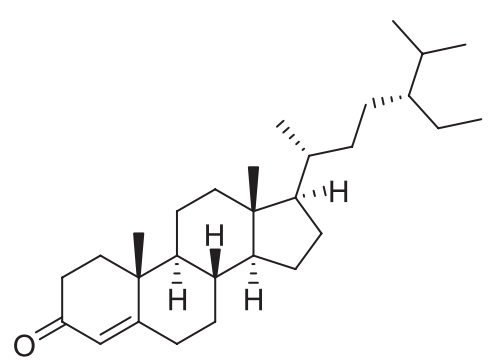

(32)<smiles>C=CC(C)CC=C(CCC(C)CCCC(C)C)C(C)CCCC(C)C</smiles>

(34)<smiles>O=C1C[C@H](c2ccc(O)c(O)c2)Oc2cc(O)ccc21</smiles><smiles>[R]CCCCCC(O)C(O)C(N)CO</smiles>

(39) $\mathrm{R}=\mathrm{C}_{9} \mathrm{H}_{19}, \Delta^{10,11}$ (40) $\mathrm{R}=\mathrm{C}_{9} \mathrm{H}_{19}$<smiles>CCCCC(CC)C(=O)OCCOCCOCCOC(=O)C(CC)CCCC</smiles>

(35)<smiles>CC1(C)CC(O)C[C@]2(C)OC(=O)C=C12</smiles>

(37)

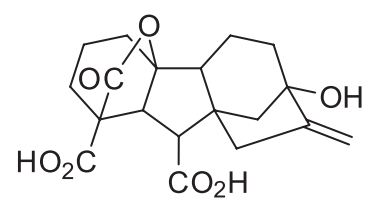

(38)<smiles>N[C@@H](CO)[C@@H](O)[C@H](O)c1ccccc1</smiles>

(41)<smiles>CCCCCCCCCCCCC(=O)OC(CO)CO</smiles>

(42)<smiles>COC(=O)C1=CO[C@@H](OC2O[C@H](CO)[C@@H](O)[C@H](O)[C@H]2O)C2C1C[C@@H](O)[C@H]2C</smiles>

(44)<smiles>Oc1ccc(/C=C/c2cc(O)cc(O)c2)cc1</smiles>

(45)<smiles>CO[C@@H]1OC=C2C(=O)O[C@H]3C=C(CO)[C@@H]1C23</smiles>

(48)

Figure 2. Structures of the identified compounds from P. nemorosa leaves. (cont.) 
<smiles>COc1cc(/C=C/C(=O)O)ccc1O</smiles>

(51)<smiles>CCC(C(N)=O)c1ccccc1</smiles>

(58)<smiles>O=C(O)CCCCCCCC(=O)O</smiles>

(52)<smiles>CN(C)CCc1ccc(O)cc1</smiles>

(56)<smiles>CC(N)C(=O)CCCCCC(=O)O</smiles>

(60)<smiles>C=C[C@H]1[C@H](CC2NCCc3c2[nH]c2ccccc32)C(C(=O)OC)=CO[C@H]1OC1CCCCC1</smiles>
(66)<smiles>O=c1c(O[R6]c2ccccc2)c(-c2ccc(O)c(O)c2)oc2cc(O)cc(O)c12</smiles>

(74)

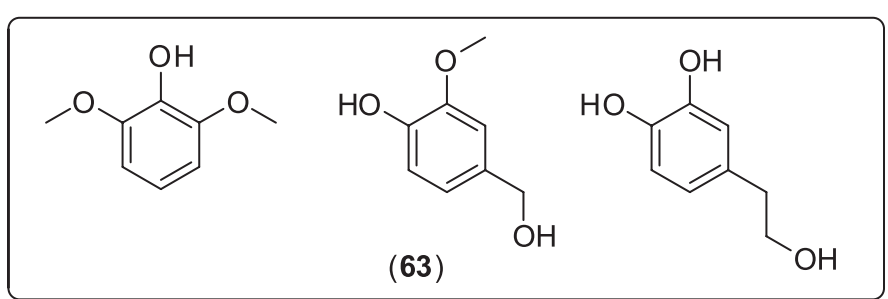<smiles>CN1CCc2c([nH]c3ccccc23)C1</smiles>

(69)<smiles>Oc1cccc(O)c1O</smiles>

(70)<smiles>O=c1c(O)c(-c2ccc(O)cc2)oc2cc(OC3CCCCC3)cc(O)c12</smiles><smiles>O=CNCCc1c[nH]c2ccccc12</smiles>

(75)

Figure 2. Structures of the identified compounds from P. nemorosa leaves. (cont.)

when compared with the vehicle group $(42.4 \pm 7.7)$ in the first phase. Analysis of the $2^{\text {nd }}$ phase of the response to formalin showed a significant inhibition at doses of 30 and $100 \mathrm{mg} \mathrm{kg}^{-1}$, with the following inhibition values: 44.2 and $62.4 \%$, respectively. The positive control groups ASA and morphine showed 46.7 and $33.3 \%$ of reduction in the licking response, respectively.

In the search for compounds exhibiting antinociceptive activity, the fractions obtained from silica gel column chromatography were tested on formalin-induced licking response in mice, and all of them were able to inhibit the phases of response to formalin (Figures 4 and 5). Only hexane/EtOAc $10 \%$ (fraction 9 that contains the sterols) and hexane/EtOAc $20 \%$ were not tested due to the small amount.
Figure 4A shows that the hexane fraction (fraction 1) was able to significantly inhibit the first phase at the dose of $100 \mathrm{mg} \mathrm{kg}^{-1}$ (41.3\% of inhibition) and in the second phase at the dose of $30 \mathrm{mg} \mathrm{kg}^{-1}$ (41.7\% of inhibition). The hexane/ EtOAc 5\% fraction (fraction 5) was able to significantly inhibit only the first phase at the dose of 30 and $100 \mathrm{mg} \mathrm{kg}^{-1}$ (45.7 and $40.1 \%$ of inhibition, respectively) (Figure 4B). The hexane/EtOAc 10\% fraction (Fraction 8) was able to significantly inhibit the first phase at the doses of 30 and $100 \mathrm{mg} \mathrm{kg}^{-1}$ (47.2 and $55.6 \%$ of inhibition, respectively) and in the second phase at the doses of 10 and $30 \mathrm{mg} \mathrm{kg}^{-1}$ (50.0 and 55.3\% of inhibition, respectively) (Figure 4C).

As previously mentioned, fraction 1 contains cinnamic acid, dihydroactinidiolide, 4-hydroxy- $\beta$-ionone and phytol, compounds that previously showed antinocicepive 


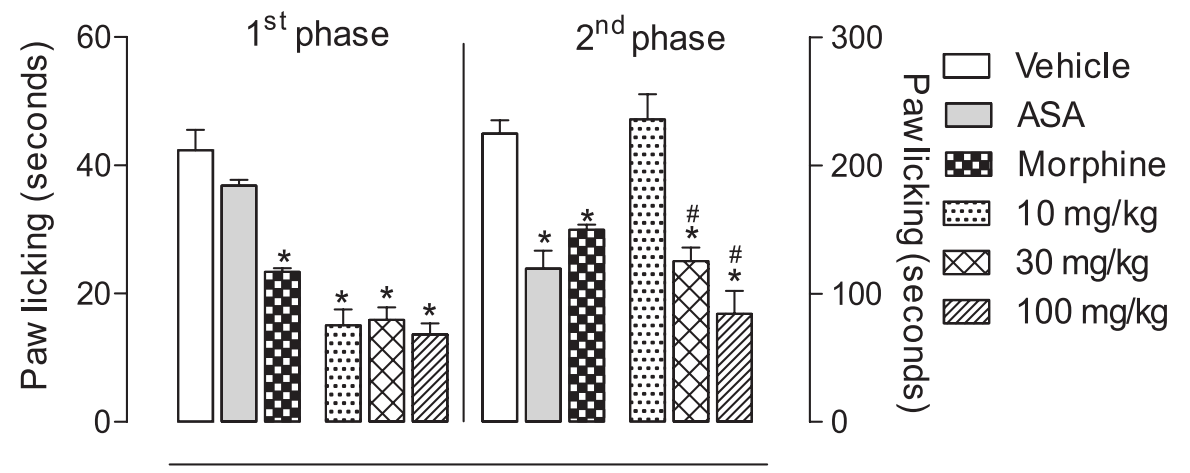

Figure 3. Effects of EE extract from P. nemorosa on formalin-induced licking response in mice. Animals were pre-treated with different doses (10, 30 or $100 \mathrm{mg} \mathrm{kg}^{-1}$, p.o.) of EE, ASA $\left(200 \mathrm{mg} \mathrm{kg}^{-1}\right)$, morphine $\left(2.5 \mathrm{mg} \mathrm{kg}^{-1}\right)$ or vehicle. The results are presented as mean \pm S.D. $(\mathrm{n}=6)$ of the time that the animal spent licking the formalin-injected paw. Statistical significance was calculated by ANOVA followed by Bonferroni's test. * $p<0.05$ when compared to vehicle-treated mice; ${ }^{\#} p<0.05$ when compared to morphine-treated mice.

activity. ${ }^{77-80} \mathrm{~A}$ mixture of oxidized and esterified triterpenes were observed in fraction 5 , as also $\alpha / \beta$-amyrin triterpenes in fraction 8 , well known for their analgesic and antiinflammatory roles. ${ }^{81-84}$

Figure 5A shows that EtOAc fraction was able to significantly inhibit the first phase at the doses of 10 , 30 and $100 \mathrm{mg} \mathrm{kg}^{-1}$ (61.7, 46.7 and $63.7 \%$ of inhibition, respectively) and in the second phase at the dose of $100 \mathrm{mg} \mathrm{kg}^{-1}$ (36.7\% of inhibition). On the other hand, $\mathrm{MeOH}$ fraction was able to significantly inhibit the first phase and the second phase at the doses of 10,30 and $100 \mathrm{mg} \mathrm{kg}^{-1}$ (71.2, 59.7 and 52.4\%; 41.7, 63.5 and 59.5\% of inhibition, respectively) (Figure 5B). This effect may be attributed, at least partially, to the phenolic compounds butin, ${ }^{85}$ resveratrol, ${ }^{86}$ ferulic acid ${ }^{87}$ and the glycosilated iridoid loganin, ${ }^{88}$ present in EtOAc fraction. Next, in the $\mathrm{MeOH}$ fraction, the great inhibition may be due to the presence of alkaloids, ${ }^{21,89,90}$ flavonoids ${ }^{91,92}$ and phenolic compounds. ${ }^{79,93} \mathrm{We}$ also tested whether the extracts could cause some effect on motor activity. The results obtained after treatment of the mice with doses of $100 \mathrm{mg} \mathrm{kg}^{-1} \mathrm{did}$ not show any effect on motor performance of mice (data not shown).

The model used to start the studies was the formalininduced licking response, as it can discriminate pain in its central and/or peripheral components; this test studies moderate and tonic pain. ${ }^{94}$ It has two distinct phases, which reflect two different types of pain. The first phase (neurogenic pain) is characterized by direct chemical stimulation of nociceptors, afferent fibers predominantly type $\mathrm{C}$ and, in part, type $\mathrm{A} \delta$, while the second phase (inflammatory pain) is characterized by the appearance of a local inflammatory process, where various proinflammatory chemical mediators are released and that can be inhibited by nonsteroidal anti-inflammatory drugs. ${ }^{95,96}$

The results showed that the $\mathrm{EE}$ and $\mathrm{MeOH}$ fraction (10,
30 and $100 \mathrm{mg} \mathrm{kg}^{-1}$ ) significantly inhibit both phases of the formalin-induced licking response. The fractions hexane (100 mg kg ${ }^{-1}$ ), hexane/EtOAc 5\%, 10\% and EtOAc (10, 30 and $100 \mathrm{mg} \mathrm{kg}^{-1}$ ) significantly inhibit the first phase. The results of the first phase suggest an antinociceptive activity that can result in both direct action on opioid receptors (predominantly type $\mu$ ), present in primary afferent fibers (type $\mathrm{C}$ ) or even an inhibition in the release of mediators such as serotonin, substance P, kinins, histamine and calcitonin gene-related peptide (CGRP). An inhibitory effect shown by EE (30 and $100 \mathrm{mg} \mathrm{kg}^{-1}$ ), hexane (30 $\left.\mathrm{mg} \mathrm{kg}^{-1}\right)$ and hexane/EtOAc 10\% (10 and $\left.30 \mathrm{mg} \mathrm{kg}^{-1}\right)$, EtOAc (100 $\left.\mathrm{mg} \mathrm{kg}^{-1}\right)$ and $\mathrm{MeOH}(10,30$ and $100 \mathrm{mg} \mathrm{kg}^{-1}$ ) in the second phase of formalin may suggest an inhibition in the formation and/or release of arachidonic acid metabolites such as prostaglandins and leukotrienes and other inflammatory mediators such as bradykinin, histamine and serotonin, as well as cytokine, eicosanoids, kinins, glutamate and nitric oxide (NO). ${ }^{94,95}$

\section{Conclusion}

In summary, it was disclosed a concise and useful way to analyze both nonpolar and polar fractions from P. nemorosa leaves through dereplication strategy. Compounds as cinnamic acid, dihydroactinidiolide, 4-hydroxy- $\beta$-ionone, phytol, isophytol, and 4,8,12,16-tetramethylheptadecan4 -olide and mainly the triterpenoids $\alpha / \beta$-amyrin, $\alpha / \beta$ amyrone, lupeol, $\alpha / \beta$-amyrin acetate, 3,11-dioxo$\alpha / \beta$-amyrene and the steroids stigmast-4-en-3-one, campesterol, stigmasterol and $\gamma$-sitosterol were identified for the first time. The triterpenes were further confirmed by standard compounds comparison arising from classical esterification and oxidation reactions, as an additional tool. The polar compounds identified were resveratrol, butin (a stilbene compound), the flavonoids rutin and 

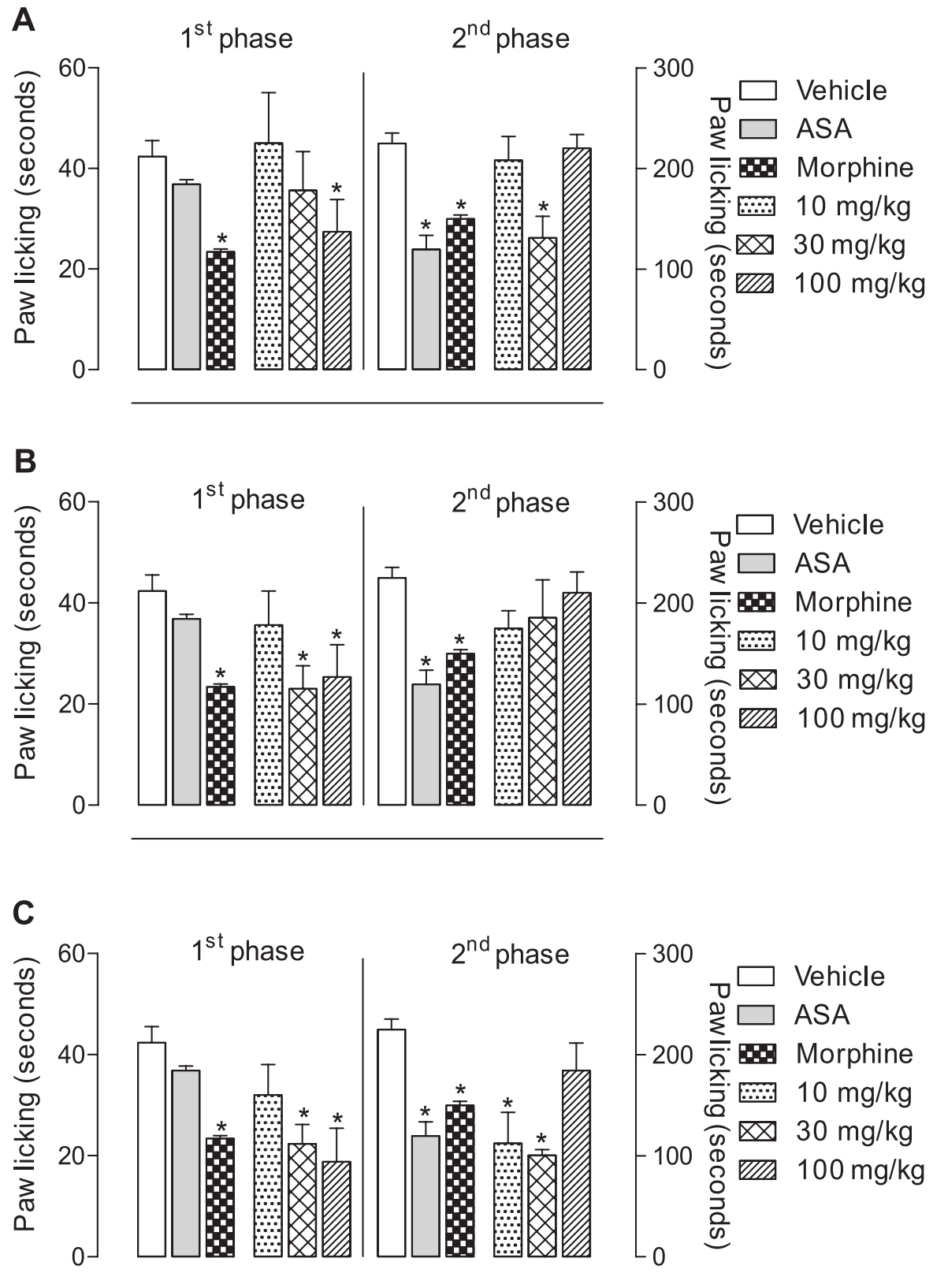

Figure 4. Effects of P. nemorosa (A) hexane fraction (fraction 1); (B) hexane/EtOAc 5\% fraction (fraction 5) and (C) hexane/EtOAc 10\% fraction (fraction 8),

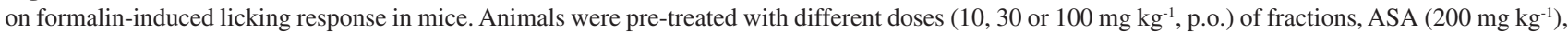
morphine $\left(2.5 \mathrm{mg} \mathrm{kg}^{-1}\right)$ or vehicle. The results are presented as mean \pm S.D. $(\mathrm{n}=6)$ of the time that the animal spent licking the formalin-injected paw. Statistical significance was calculated by ANOVA followed by Bonferroni's test. ${ }^{*} p<0.05$ when compared to vehicle-treated mice.

kaempferol 7-O- $\beta$-D-glucopyranoside; the iridoid glycosides deacetylasperuloside, epiloganin, and alkaloids as hordenine, stryctosidine, $N$-methyl-1,2,3,4-tetrahydro$\beta$-carboline and $N$-formyl-tryptamine.

Furthermore, to the best of our knowledge, this is the first work describing the phytochemical profile and antinociceptive properties of $P$. nemoros $a$ leaves. The extract and fractions were able to produce an oral antinociceptive effect in acute pain model in mice (formalin-induced licking response).

\section{Supplementary Information}

Supplementary data are available free of charge at http://jbcs.sbq.org.br as a PDF file.

\section{Acknowledgments}

The authors thank the State of Rio de Janeiro Research Foundation (FAPERJ) for financial support and José Carlos Tomaz (Núcleo de Pesquisa em Produtos Naturais e 

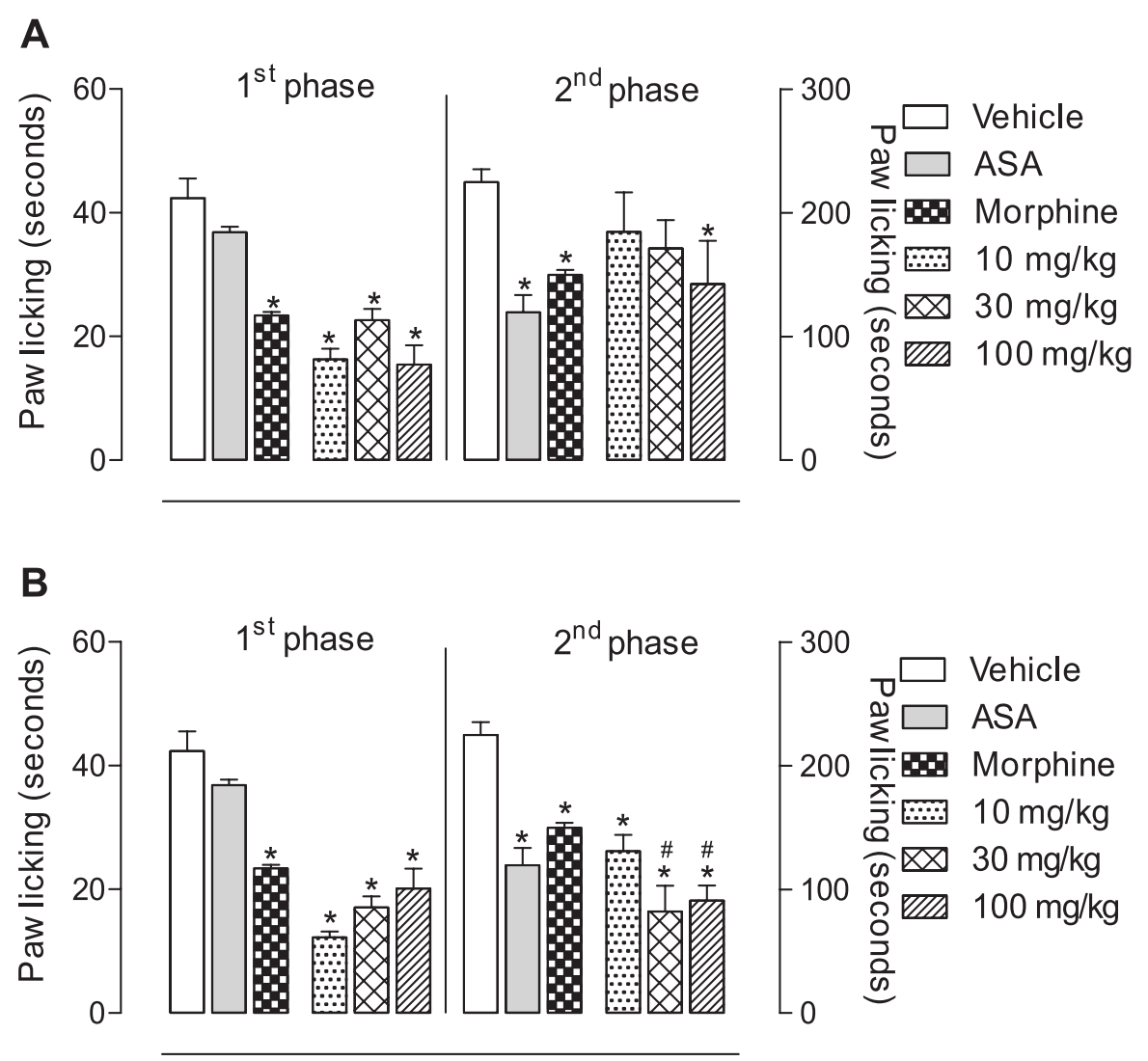

Figure 5. Effects of P. nemorosa (A) EtOAc and (B) MeOH fractions on formalin-induced licking response in mice. Animals were pre-treated with different doses $\left(10,30\right.$ or $100 \mathrm{mg} \mathrm{kg}^{-1}$, p.o.) offractions, ASA $\left(200 \mathrm{mg} \mathrm{kg}^{-1}\right)$, morphine $\left(2.5 \mathrm{mg} \mathrm{kg}^{-1}\right)$ or vehicle. The results are presented as mean \pm S.D. $(\mathrm{n}=6)$ of the time that the animal spent licking the formalin-injected paw. Statistical significance was calculated by ANOVA followed by Bonferroni's test. * $p<0.05$ when compared to vehicle-treated mice; ${ }^{*} p<0.05$ when compared to morphine-treated mice.

Sintéticos (NPPS), Department of Physics and Chemistry, Faculty of Pharmaceutical Sciences, University of São Paulo) for mass spectrometer assistance.

\section{References}

1. Calixto, J. B.; Braz. J. Med. Biol. Res. 2000, 33, 179.

2. Patwardhan, B.; J. Ethnopharmacol. 2005, 100, 50.

3. Cordell, G. A.; Shin, Y. G.; Pure Appl. Chem. 1999, 71, 1089.

4. Ernst, M.; Silva, D. B.; Silva, R. R.; Vêncio, R. Z.; Lopes, N. P.; Nat. Prod. Rep. 2014, 31, 784.

5. Lang, G.; Mayhudin, N. A.; Mitova, M. I.; Sun, L.; van der Sar, S.; Blunt, J. W.; Cole, A. L. J.; Ellis, G.; Laatsch, H.; Munro, M. H. G.; J. Nat. Prod. 2008, 71, 1595.

6. He, M.; Lv, H.-Y.; Li, Y.-P.; Gonçalves, C. M. V.; Dong, N.-P.; Pan, L.-S.; Liu, P.-L.; Liang, Y.-Z.; Anal. Methods 2014, 6, 2239.

7. Pinto, A. C.; Vessecchi, R.; Silva, C. G.; Amorim, A. C. L.; Santos Júnior, H. M.; Rezende, M. J. C.; Gates, P. J.; Rezende, C. M.; Lopes, N. P.; Rapid Commun. Mass Spectrom. 2015, $29,1$.

8. Davis, A. P.; Bridson, D.; Jarvis, C.; Govaerts, R. L.; Bot. J. Linn. Soc. 2001, 135, 35.
9. Razafimandimbison, S. G.; Taylor, C. M.; Wikström, N.; Pailler, T.; Khodabandeh, A.; Bremer, B.; Am. J. Bot. 2014, 101, 1102.

10. Watt, J. M.; Breyer-Brandwijk, M. G.; The Medicinal and Poisonous Plants of Southern and Eastern Africa, $2^{\text {nd }}$ ed.; E. \& S. Livingstone: London, United Kingdom, 1962.

11. Locher, C. P.; Burch, M. T.; Mower, H. F.; Berestecky, J.; Davis, H.; Van Poel, B.; Lasure, A.; Vanden Berghe, D. A.; Vlietinck, A. J.; J. Ethnopharmacol. 1995, 49, 23.

12. McGaw, L. J.; Jager, A. K.; van Staden, J.; J. Ethnopharmacol. 2000, 72, 247.

13. Moraes, T. M.; Araújo, M. H.; Bernardes, N. R.; Oliveira, D. B.; Lasunskaia, E. B.; Muzitano, M. F.; Cunha, M.; Planta Med. 2011, 77, 964.

14. Witherup, K. M.; Bogusky, M. J.; Anderson, P. M.; Ramjit, H.; Ransom, R. W.; Wood, T.; Sardana, M.; J. Nat. Prod. 1994, 57, 1619.

15. Lopes, S. O.; Poser, G. L. V.; Kerber, V. A.; Farias, F. M.; Konrath, E. L.; Moreno, P.; Sobral, M. E.; Zuanazzi, J. A. S.; Henriques, A. T.; Biochem. Syst. Ecol. 2004, 32, 1187.

16. Formagio, A. S. N.; Volobuff, C. R. F.; Santiago, M.; Cardoso, C. A. L.; Vieira, M. C.; Pereira, Z. V.; Antioxidants 2014, 3, 745 . 
17. Moreno, B. P.; Fiorucci, L. L. R.; Carmo, M. R. B.; Sarragiotto, M. H.; Baldoqui, D. C.; Biochem. Syst. Ecol. 2014, 56, 80.

18. Taylor, C.; http://floradobrasil.jbrj.gov.br/jabot/floradobrasil/ FB14153, accessed in July 2016.

19. Paiva, A. M.; Lopes, R. C.; http://www.anchietano.unisinos.br/ publicacoes/botanica/botanica64/03_paiva\%20e\%20lopes.pdf, accessed in July 2016.

20. Both, F. L.; Farias, F. M.; Nicoláo, L. L.; Misturini, J.; Henriques, A. T.; Elisabetsky, E.; Rev. Bras. Plant. Med. 2002, 5,41 .

21. Elisabetsky, E.; Amador, T. A.; Albuquerque, R. R.; Nunes, D. S.; Carvalho, A. C. T.; J. Ethnopharmacol. 1995, 48, 77.

22. Castana, O.; Anagiotos, G.; Rempelos, G.; Adalopoulou, A.; Kokkinakis, C.; Giannakidou, M.; Diplas, D. B.; Alexakis, D.; Ann. Burns Fire Disasters 2009, 22, 88.

23. Niv, D.; Kreitler, S.; Pain Pract. 2001, 1, 150.

24. Woodcock, J.; Witter, J.; Dionne, R. A.; Nat. Rev. Drug Discov. 2007, 6, 703.

25. Patitucci, M. L.; Veiga Jr., V. F.; Pinto, A. C.; Zoghbi, M. G. B.; Silva, J. R. A.; Quim. Nova 1995, 18, 262.

26. Bandeira, P. N.; Lemos, T. L. G.; Costa, S. M. A.; Santos, H. S.; Rev. Bras. Farmacogn. 2007, 17, 204.

27. Barnes, R. A.; Pereira, A. L.; Scofield, T. C.; Braz-Filho, R.; Pinto, A. C.; Chem. Pharm. Bull. 1984, 32, 3674.

28. Pinto, A. C.; Pereira, A. L.; Kelecom, A.; Porreca, L. M.; Ribeiro, N. M.; Barnes, R. A.; Chem. Pharm. Bull. 1988, 36, 4689.

29. Gomes, N. M.; Rezende, C. M.; Fontes, S. P.; Matheus, M. E.; Fernandes, P. D.; J. Ethnopharmacol. 2007, 109, 486.

30. Abad-Garcia, B.; Berrueta, L. A.; Garmon-Lobato, S.; Gallo, B.; Vicente, F.; J. Chromatogr. A 2009, 1216, 5398.

31. Dubuisson, D.; Dennis, S. G.; Pain 1977, 4, 161.

32. Lu, Q.; Wang, J.; Kong, L.; Biochem. Syst. Ecol. 2014, 52, 20.

33. Lu, Q.; Wang, J.; Luo, J.; Wang, X.; Shan, S.; Kong, L.; Nat. Prod. Res. 2014, 28, 1659.

34. Andrade, J. M. M.; Biegelmeyer, R.; Xavier, C. A. G.; Bordignon, S. A. L.; Moreno, P. R. H.; Zuanazzi, J. A. S.; Henriques, A. T.; Apel, M. A.; Chem. Nat. Compd. 2010, 46, 649.

35. Gonzalez, J.; Dieck, T.; Rev. Latinoam. Quim. 1996, $24,7$.

36. Li, H.-F.; Huang, J.; Liu, M.-S.; Zhang, X.-P.; Chin. J. Exp. Trad. Med. Formulae 2011, 19, 125.

37. Pimenta, A. T. A.; Uchôa, D. E. A.; Braz-Filho, R.; De Souza, E. B.; Silveira, E. R.; Lima, M. A. S.; J. Braz. Chem. Soc. 2011, $22,2216$.

38. Achenbach, H.; Lottes, M.; Waibel, R.; Karikas, G. A.; Correa, M. D. A.; Gupta, M. P.; Phytochemistry 1995, 38, 1537.

39. Dan, S.; Dan, S. S.; Fitoterapia 1986, 57, 445.

40. Lee, K.-H.; Lin, Y.-M.; Wu, T.-S.; Zhang, D.-C.; Yamagishi, T.; Hayashi, T.; Hall, I. H.; Chang, J.-J.;Wu, R.-Y.;Yang, T.-H.; Planta Med. 1988, 54, 308.

41. Assimopoulou, A. N.; Papageorgiou, V. P.; Biomed. Chromatogr. 2005, 19, 285.
42. Dias, M. O.; Hamerski, L.; Pinto, A. C.; Quim. Nova 2011, 34, 704.

43. Branco, A.; Pinto, A. C.; Braz Filho, R.; An. Acad. Bras. Ciênc. 2004, 76, 505.

44. Ermer, J.; Vogel, M.; Biomed. Chromatogr. 2000, 14, 373.

45. Chernushevich, I. V.; Loboda, A. V.; Thomson, B. A.; J. Mass Spectrom. 2001, 36, 849.

46. Demarque, D. P.; Crotti, A. E. M.; Vessecchi, R.; Lopes, J. L. C.; Lopes, N. P. Nat. Prod. Rep. 2016, 33, 432.

47. Tan, M. A.; Panghulan, G. F. M.; Uy, M. M.; Takayama, H.; Am. J. Essent. Oils Nat. Prod. 2014, 1, 18.

48. Kerber, V. A.; Gregianini, T. S.; Paranhos, J. T.; Schwambach, J.; Farias, F.; Fett, J. P.; Fett-Neto, A. G.; Zuanazzi, J. A. S.; Quirion, J. C.; Elizabetsky, E.; Henriques, A. T.; J. Nat. Prod. 2001, 64, 677.

49. Liu, R.; Ye, M.; Guo, H.; Bi, K.; Guo, D. A.; Rapid Commun. Mass Spectrom. 2005, 19, 1557.

50. Antal, D. S.; Schwaiger, S.; Ellmerer-Muller, E. P.; Stuppner, H.; Planta Med. 2010, 76, 1765.

51. Jin, M. J.; Kim, I. S.; Rehman, S. U.; Dong, M. S.; Na, C. S.; Yoo, H. H.; J. Chromatogr. Sci. 2015, 24, 1.

52. Valdés III, L. J.; J. Nat. Prod. 1986, 49, 171.

53. Takahashi, N.; Murofushi, N.; Yokota, T.; Tamura, S.; Kato, J.; Shiotani, Y.; Tetrahedron Lett. 1967, 48, 4861.

54. Peer, M.; Stegmann, M.; Mueller, M. J.; Waller, F.; FEBS Lett. 2010, $584,4053$.

55. Huang, Y.; Liu, X.; Zhao, L.; Li, F.; Xiong, Z.; Biomed. Chromatogr. 2014, 28, 878.

56. Cravatt, B. F.; Lerner, R. A.; Boger, D. L.; J. Am. Chem. Soc. 1996, $118,580$.

57. Limb, J.-K.; Kim, Y. H.; Han, S.-Y.; Jhon, G.-J.; J. Lipid Res. 1999, 40, 2169.

58. Xiao-Qin, L.; Xiao-Hong, S.; Shuang, C.; Xi-Xiang, Y.; Fa-Mei, L.; Acta Pharm. Sin. B 2009, 44, 895.

59. Quirantes-Piné, R.; Lozano-Sánchez, J.; Herrero, M.; Ibáñez, E.; Segura-Carretero, A.; Fernández-Gutiérrez, A.; Phytochem. Anal. 2013, 24, 213.

60. Trela, B. C.; Waterhouse, A. L.; J. Agric. Food Chem. 1996, 44, 1253.

61. Stella, L.; Rosso, M.; Panighel, A.; Vedova, A. D.; Flamini, R.; Traldi, P.; Rapid Commun. Mass Spectrom. 2008, 22, 3867.

62. Jiang, W.; Jin, D.; Li, Z.; Sun, Z.; Chen, M.; Wu, B.; Huang, C.; Biomed. Chromatogr. 2012, 26, 863.

63. Wang, X.; Cheng, W.; Yao, X.; Guo, X.; Nat. Prod. Res. 2012, 26, 167.

64. Hossain, M.; Dilip, R.; Brunton, N.; Martin-Diana, A. B.; BarryRyan, C.; J. Agric. Food Chem. 2010, 58, 10576.

65. Stanisavljević, N. S.; Ilić, M.; Jovanović,Ž. S.; Čupić, T.; Dabić, D. Č.; Natić, M. M.; Tešić, Ž. L.; Radović, S. S.; Arch. Biol. Sci. (Belgrade) 2015, 67, 829.

66. Holser, R. A.; ISRN Spectrosc. 2012, 2012, 1. 
67. http://www.massbank.jp/jsp/Dispatcher.jsp?type $=$ disp\&id= KO000123\&site=0, accessed in July 2016.

68. Kadam, T. V.; Darekar, A. B.; Gondkar, S. B.; Saudagar, R. B.; Asian J. Res. Pharm. Sci. 2015, 5, 83.

69. Rivier, L.; Lindgren, J.; Econ. Bot. 1972, 26, 101.

70. Berger, A.; Fasshuber, H.; Schinnerl, J.; Brecker, L.; Greger, H.; Phytochem. Lett. 2012, 5, 558.

71. Yamazaki, Y.; Urano, A.; Sudo, H.; Kitajima, M.; Takayama, H.; Yamazaki, M.; Aimi, N.; Saito, K.; Phytochemistry 2003, 62,461 .

72. Gribble, G. W.; Nelson, R. B.; J. Org. Chem. 1974, 39, 1845.

73. Tiberti, L. A.; Yariwake, J. H.; Ndjokob, K.; Hostettmann, K.; J. Braz. Chem. Soc. 2007, 18, 100.

74. Lopes-Lutz, D.; Dettmann, J.; Nimalaratne, C.; Schieber, A.; Molecules 2010, 15, 8543.

75. Sánchez-Rabaneda, F.; Jáuregui, O.; Casals, I.; Andrés-Lacueva, C.; Izquierdo-Pulido, M.; Lamuela-Raventó, R. M.; J. Mass Spectrom. 2003, 38, 35.

76. Schieber, A.; Mihalev, K.; Berardini, N.; Mollov, P.; Carle, R.; Z. Naturforsch, C.: J. Biosci. 2005, 60, 379.

77. Gershenzon, J.; Dudareva, N.; Nat. Chem. Biol. 2007, 3, 408.

78. Zhang, J.; Rapier, A.; Radhakrishnan, R.; Light, A.; J. Pain 2010, 11, S52.

79. Cavalcante-Silva, L. H. A.; Matta, C. B. B.; Araújo, M. V.; Barbosa-Filho, J. M.; Lira, D. P.; Santos, B. V. O.; Miranda, G. E. C.; Alexandre-Moreira, M. S.; Mar. Drugs 2012, 10, 1977.

80. Santos, C. C. M. P.; Salvadori, M. S.; Mota, V. G.; Costa, L. M.; Almeida, A. A. C.; Oliveira, G. A. L.; Costa, J. P.; Sousa, D. P.; Freitas, R. M.; Almeida, R. N.; Neurosci. J. 2013, 2013, 1.

81. Mahato, S. B.; Nandy, A. K.; Roy, G.; Phytochemistry 1992, 31, 2199.

82. Pinto, S. A. H.; Pinto, L. M. S.; Guedes, M. A.; Cunha, G. M. A.; Chaves, M. H.; Santos, F. A.; Rao, V. S.; Phytomedicine 2008, 15, 630 .
83. Soldi, C.; Pizzolatti, M. G.; Luiz, A. P.; Marcon, R.; Meotti, F. C.; Mioto, L. A.; Santos, A. R. S.; Bioorg. Med. Chem. 2008, 16, 3377 .

84. Fingolo, C. E.; Santos, T. S.; Vianna Filho, M. D. M.; Kaplan, M. A. C.; Molecules 2013, 18, 4247.

85. Bhargava, S. K.; J. Ethnopharmacol. 1986, 18, 95.

86. Torres-López, J. E.; Ortiz, M. I.; Castañeda-Hérnandez, G.; Alonso-López, R.; Asomoza-Espinosa, R.; Granados-Soto, V.; Life Sci. 2002, 70, 1669.

87. Lv, W. H.; Zhang, L.; Wu, S. J.; Chen, S. Z.; Zhu, X. B.; Pan, J. C.; Zhongguo Zhongyao Zazhi 2013, 38, 3736.

88. Gong, N.; Fan, H.; Ma, A.-N.; Xiao, Q.; Wang, Y.-X.; Neuropharmacology 2014, 84, 31.

89. Elisabetsky, E.; Castilhos, Z. C.; Int. J. Crude Drug Res. 1990, $28,49$.

90. Radulovic, N. S.; Blagojevic, P. D.; Randjelovic, P. J.; Stojanovic, N. M.; Curr. Top Med. Chem. 2013, 13, 2134.

91. De Melo, G. O.; Malvar, D. C.; Vanderlind, F. A.; Rocha, F. F.; Pires, P. A.; Costa, E. A.; Matos, L. G.; Kaiser, C. R.; Costa, S. S.; J. Ethnopharmacol. 2009, 124, 228.

92. Selvaraj, G.; Kaliamurthi, S.; Thirungnasambandam, R.; Vivekanandan, L.; Balasubramanian, T.; Biomed. Environ. Sci. 2014, 27, 295.

93. Küpeli, E.; Sahin, F. P.; Yesilada, E.; Caliş, İ.; Ezer, N.; Z. Naturforsch. C: J. Biosci. 2007, 62, 519.

94. Hunskaar, S.; Fasmer, O. B.; Hole, K.; J. Neurosci. Methods 1985, 14, 69.

95. Hunskaar, S.; Hole, K.; Pain 1987, 30, 103.

96. Chichorro, J. G.; Lorenzetti, B. B.; Zampronio, A. R.; Br. J. Pharmacol. 2004, 141, 1175.

Submitted: May 9, 2016 Published online: July 25, 2016

FAPESP has sponsored the publication of this article. 